\title{
Putative Nucleotide-Based Second Messengers in the Archaeal Model Organisms Haloferax volcanii and Sulfolobus acidocaldarius
}

\author{
Frank Braun ${ }^{1}$, Alejandra Recalde ${ }^{1}$, Heike Bähre ${ }^{2}$, Roland Seifert ${ }^{2}$ and \\ Sonja-Verena Albers ${ }^{1 *}$ \\ ${ }^{1}$ Molecular Biology of Archaea, Institute of Biology, University of Freiburg, Freiburg, Germany, ${ }^{2}$ Research Core Unit \\ Metabolomics, Hannover Medical School, Hanover, Germany
}

OPEN ACCESS

Edited by:

Zhe Lyu,

Baylor College of Medicine,

United States

Reviewed by:

Jörg Stülke,

University of Göttingen, Germany Natalia Tschowri,

Leibniz University Hannover, Germany Michael Y. Galperin,

National Center for Biotechnology

Information (NLM), United States

*Correspondence:

Sonja-Verena Albers

sonja.albers@biologie.uni-freiburg.de

Specialty section:

This article was submitted to

Biology of Archaea,

a section of the journal

Frontiers in Microbiology

Received: 17 September 2021 Accepted: 01 November 2021

Published: 22 November 2021

Citation:

Braun F, Recalde A, Bähre H, Seifert $R$ and Albers S-V (2021)

Putative Nucleotide-Based Second Messengers in the Archaeal Model

Organisms Haloferax volcani

and Sulfolobus acidocaldarius.

Front. Microbiol. 12:779012. doi: 10.3389/fmicb.2021.779012
Research on nucleotide-based second messengers began in 1956 with the discovery of cyclic adenosine monophosphate $\left(3^{\prime}, 5^{\prime}\right.$-cAMP) by Earl Wilbur Sutherland and his co-workers. Since then, a broad variety of different signaling molecules composed of nucleotides has been discovered. These molecules fulfill crucial tasks in the context of intracellular signal transduction. The vast majority of the currently available knowledge about nucleotide-based second messengers originates from model organisms belonging either to the domain of eukaryotes or to the domain of bacteria, while the archaeal domain is significantly underrepresented in the field of nucleotide-based second messenger research. For several well-stablished eukaryotic and/or bacterial nucleotide-based second messengers, it is currently not clear whether these signaling molecules are present in archaea. In order to shed some light on this issue, this study analyzed cell extracts of two major archaeal model organisms, the euryarchaeon Haloferax volcanii and the crenarchaeon Sulfolobus acidocaldarius, using a modern mass spectrometry method to detect a broad variety of currently known nucleotide-based second messengers. The nucleotides $3^{\prime}, 5^{\prime}$-cAMP, cyclic guanosine monophosphate ( $3^{\prime}, 5^{\prime}$-cGMP), 5'-phosphoadenylyl-3',5'-adenosine $\left(5^{\prime}-\mathrm{pApA}\right)$, diadenosine tetraphosphate $\left(\mathrm{Ap}_{4} \mathrm{~A}\right)$ as well as the $2^{\prime}, 3^{\prime}$-cyclic isomers of all four RNA building blocks ( $2^{\prime}, 3^{\prime}$-cNMPs) were present in both species. In addition, $H$. volcanii cell extracts also contain cyclic cytosine monophosphate $\left(3^{\prime}, 5^{\prime}-c C M P\right)$, cyclic uridine monophosphate $\left(3^{\prime}, 5^{\prime}-\mathrm{cUMP}\right)$ and cyclic diadenosine monophosphate ( $3^{\prime}, 5^{\prime}$-c-di-AMP). The widely distributed bacterial second messengers cyclic diguanosine monophosphate $\left(3^{\prime}, 5^{\prime}-\mathrm{c}-\mathrm{di}-\mathrm{GMP}\right)$ and guanosine (penta-)/tetraphosphate [(p)ppGpp] could not be detected. In summary, this study gives a comprehensive overview on the presence of a large set of currently established or putative nucleotide-based second messengers in an eury- and a crenarchaeal model organism.

Keywords: archaea, Haloferax volcanii, Sulfolobus acidocaldarius, cyclic nucleotides, second messengers, signaling molecules 


\section{INTRODUCTION}

During cellular signal transduction, most external/environmental stimuli do not directly interact with their respective cellular target, but rather cause the intracellular production/release of specific small molecules, which transmit the initial signal and eventually trigger a specific cellular response. In this concept, the initial stimulus is referred to as "first messenger," while the intracellularly transducing small molecules are called "second messengers" (Newton et al., 2016). Various second messengers have been identified and they can be grouped into four different categories according to their chemical properties: ions, gases and free radicals, lipid-based and nucleotide-based second messengers (Newton et al., 2016). Calcium $\left(\mathrm{Ca}^{2+}\right)$ is a well-established ionic second messenger, which plays a crucial role in a plethora of eukaryotic signal transduction processes such as the excitability of neural cells, exocytosis, motility, apoptosis, and transcription (Clapham, 2007). A well-characterized example of a gaseous second messenger is nitric oxide (NO). Molecules of this gas are involved in various prokaryotic and eukaryotic signal transduction pathways, such as the regulation of the mammalian nervous system and bacterial quorum sensing and biofilm formation (Zhou and Zhu, 2009; Nisbett and Boon, 2016). Examples of lipid-based second messengers are diacylglycerol or ceramide, which are involved in various eukaryotic signal cascades (Liscovitch and Cantley, 1994; Hilgemann et al., 2018). The most diverse category of second messengers consists of nucleotide-based signaling molecules. These second messengers can either be based on a single (mono-nucleotide-based), two (di-nucleotide-based), or several (oligo-nucleotide-based) nucleotide molecules. Table $\mathbf{1}$ shows an overview on the majority of currently established or putative nucleotide-based second messengers, including their presence and some examples of their functions in eukaryotes and bacteria.

The information summarized in Table 1 originates from bacteria and eukaryotes. For archaea, only very limited information about the occurrence and the physiological functions of nucleotide-based second messengers is currently available. Until now, only the presence of $3^{\prime}, 5^{\prime}$-cAMP, $3^{\prime}, 5^{\prime}$-cdi-AMP and cyclic oligo adenylate ( $\mathrm{COA}$ ) has been reported in archaea. $3^{\prime}, 5^{\prime}$-cAMP was identified in the euryarchaea Haloferax volcanii and Methanothermobacter thermoautotrophicus and in the crenarchaea Saccharolobus solfataricus (previously known as Sulfolobus solfataricus) (Leichtling et al., 1986). Additionally, in the euryarchaeon Halobacterium salinarum the levels of $3^{\prime}, 5^{\prime}$-cAMP were shown to fluctuate during the cell cycle (Baumann et al., 2007). Analogous to its reported function in bacteria, $\mathrm{COA}$ was shown to be involved in type III CRISPR system mediated immunity in the crenarchaeon Sa. solfataricus (Rouillon et al., 2018). In H. volcanii, $3^{\prime}, 5^{\prime}$-cdi-AMP was shown to be essential and has been implicated in osmoregulation (Braun et al., 2019). Noteworthy, analysis of the presence of the alarmone (p)ppGpp using radioisotopelabeling approaches in a few archaeal species suggested the absence of this signaling nucleotide (Beauclerk et al., 1985;
Cimmino et al., 1993; Scoarughi et al., 1995; Cellini et al., 2004). For all other nucleotide-based second messengers there is, to the best of our knowledge, currently no data available whether or not they are produced in archaea. To study the presence of nucleotide-based second messengers in archaea, cell extracts of the euryarchaeal model organism $H$. volcanii and the crenarchaeal model organism S. acidocaldarius were analyzed using liquid chromatography tandem mass spectrometry (LC-MS/MS) for the presence of representatives of mono-, di-, and oligo-nucleotide-based second messengers. These measurements unveiled that $H$. volcanii cells contain, besides the already known $3^{\prime}, 5^{\prime}$-cAMP and $3^{\prime}, 5^{\prime}$-c-di-AMP, detectable levels of $3^{\prime}, 5^{\prime}$-cGMP, $3^{\prime}, 5^{\prime}$-cCMP, $3^{\prime}, 5^{\prime}$-cUMP, $2^{\prime}, 3^{\prime}$-cAMP, $2^{\prime}, 3^{\prime}$-cGMP, $2^{\prime}, 3^{\prime}$-cCMP, 2', $3^{\prime}$-cUMP, $5^{\prime}$-pApA and Ap ${ }_{4} \mathrm{~A}$. Compared to that, $S$. acidocaldarius cells contained a reduced variety of nucleotides. Besides all four $2^{\prime}, 3^{\prime}$-cNMPs, only $3^{\prime}, 5^{\prime}$-cAMP, $3^{\prime}, 5^{\prime}$-cGMP, $\mathrm{Ap}_{4} \mathrm{~A}$ and very minor amounts of $5^{\prime}$-pApA could be detected. The well-established bacterial second messenger $3^{\prime}, 5^{\prime}$-c-di-GMP, the alarmone (p)ppGpp as well as all three physiologically appearing isomers of cGAMP (2',3'-cGAMP, 3', $3^{\prime}$-cGAMP, and $3^{\prime}, 2^{\prime}$-cGAMP) could not be detected, suggesting their absence in $H$. volcanii and S. acidocaldarius when grown under standard laboratory conditions. The same applies for $3^{\prime}, 5^{\prime}$-cTMP, $3^{\prime}, 5^{\prime}$-cIMP, $3^{\prime}, 5^{\prime}$-cXMP, $5^{\prime}$-pGpG and cOA $(n=4$; c-tetra-AMP $)$, which were all not present in the examined $H$. volcanii and S. acidocaldarius cell extracts.

Taken together, the results of this study show that the nucleotide-based second messenger pools of $H$. volcanii and $S$. acidocaldarius contain several signaling molecules, whose presence in archaea has not been shown so far. Assuming that many other euryarchaeal and crenarchaeal species make use of similar nucleotide-based second messenger pools, these results offer important leads to further investigate the role and importance of these nucleotides for these organisms.

\section{MATERIALS AND METHODS}

Unless stated otherwise all chemicals were purchased from Carl Roth.

\section{Strains and Growth Conditions}

H. volcanii strain $\mathrm{H} 26$ was grown in selective CA medium (Allers et al., 2004) (0.5 g/L Bacto ${ }^{\text {TM }}$ Casamino acids; pH 7.2 adjusted with $\mathrm{KOH}$ ) modified with an expanded trace element solution (referred to as CAB) (Duggin et al., 2015). Cells were grown at $45^{\circ} \mathrm{C}$ in liquid medium while rotating (volumes up to $5 \mathrm{ml}$ ) or shaking (volumes $>5 \mathrm{ml}$ ).

S. acidocaldarius strain MW001 was grown in basal Brock medium (pH 3.5) (Brock et al., 1972) supplemented with 0.1\% $(\mathrm{w} / \mathrm{v}) \mathrm{NZ}$-amine (Sigma) and $0.2 \%(\mathrm{w} / \mathrm{v})$ dextrin. Cells were grown at $75^{\circ} \mathrm{C}$ in liquid medium while shaking.

Since both strains are auxotroph for uracil (H26, $\triangle p y r E 2$ and MW001, $\triangle p y r E F)$, growth media were supplemented with uracil (Sigma) at a defined concentration $(50 \mu \mathrm{g} / \mathrm{ml}$ for $\mathrm{H} 26 ; 10 \mu \mathrm{g} / \mathrm{ml}$ 
TABLE 1 | Overview on occurrence and exemplary function(s) in eukaryotes and bacteria of all signaling nucleotides addressed in this study.

\begin{tabular}{|c|c|c|c|c|}
\hline Nucleotide(s) & Presence in eukaryotes & Exemplary functions in eukaryotes & Presence in bacteria & Exemplary functions in bacteria \\
\hline \multicolumn{5}{|c|}{ Mono-nucleotide-based signaling molecules } \\
\hline $3^{\prime}, 5^{\prime}$-cIMP & $\begin{array}{l}\text { Identified in isolated porcine } \\
\text { coronary arteries (Chen } \\
\text { et al., 2014) }\end{array}$ & $\begin{array}{l}\text { - In general functions are currently mostly } \\
\text { unknown (Leung et al., 2015) } \\
\text { - Involved in hypoxia-induced constriction } \\
\text { of porcine coronary arteries (Chen et al., } \\
\text { 2014; Nan et al., 2020) }\end{array}$ & \multicolumn{2}{|c|}{$\begin{array}{l}\text { - Only very few data available } \\
\text { - Detected in Corynebacterium murisepticum (Newton et al., } \\
\text { 1998); specificity of the used method is however questioned } \\
\text { (Seifert, 2015) }\end{array}$} \\
\hline $\begin{array}{l}3^{\prime}, 5^{\prime}-\mathrm{cTMP} \\
3^{\prime}, 5^{\prime}-\mathrm{cXMP}\end{array}$ & \multicolumn{4}{|c|}{$\begin{array}{l}\text { Not yet detected in any biological samples using modern and sensitive mass spectrometry techniques (Beste and Seifert, 2013) } \\
\text { cXMP can be formed by purified guanylate cyclase and activate certain cAMP effectors in vitro (Wolter et al., 2011; Beste et al., 2012) }\end{array}$} \\
\hline $2^{\prime}, 3^{\prime}-\mathrm{cNMPs}$ & $\begin{array}{l}\text { Identified in several } \\
\text { mammalian cell lines (Ren } \\
\text { et al., 2009; Pabst et al., } \\
\text { 2010; Bähre and Kaever, } \\
\text { 2014), different organs (Jia } \\
\text { et al., 2014) and plant } \\
\text { tissue (Van Damme et al., } \\
\text { 2014) }\end{array}$ & $\begin{array}{l}\text { - Originate from mRNA degradation by } \\
\text { transphosphorylation (Thompson et al., } \\
\text { 1994) or RNA cyclase activity (Shigematsu } \\
\text { et al., 2018) } \\
\text { - Actual utilization as second messengers } \\
\text { currently unknown; reporting of tissue } \\
\text { damage as possible function (Jackson, } \\
\text { 2011, 2017; Van Damme et al., 2014) }\end{array}$ & $\begin{array}{l}\text { Identified in f.i.: } \\
\text { - Pseudomonas fluorescens } \\
\text { (Bordeleau et al., 2014) } \\
\text { - E. coli (Fontaine et al., 2018) }\end{array}$ & $\begin{array}{l}\text { - In E. coli originating from RNase } \\
\text { I-dependent RNA degradation } \\
\text { (Fontaine et al., 2018) or RNA cyclase } \\
\text { activity (Genschik et al., 1997) } \\
\text { - Levels of 2',3'-cNMPs influenced the } \\
\text { biofilm formation of E. coli (Fontaine } \\
\text { et al., 2018) }\end{array}$ \\
\hline \multicolumn{5}{|c|}{ Di-nucleotide-based signaling molecules } \\
\hline $3^{\prime}, 5^{\prime}$-c-di-GMP & \multicolumn{2}{|c|}{$\begin{array}{l}\text { - Synthesizing and degrading enzymes bioinformatically predicted } \\
\text { in lower eukaryotes (Römling et al., 2013) } \\
\text { - Synthesis confirmed in social amoebae of the class of Dictyostelia } \\
\text { with a function for stalk cell differentiation (Chen and Schaap, 2012) } \\
\text { - Recognized by human innate immune system (Burdette et al., } \\
\text { 2011) }\end{array}$} & $\begin{array}{l}\text { In species of various phyla } \\
\text { (Römling et al., 2013) }\end{array}$ & $\begin{array}{l}\text { - Involvement in various physiological } \\
\text { functions observed (Römling et al., } \\
\text { 2005) } \\
\text { - Major functions: Transition from motile } \\
\text { to sessile lifestyle (Wolfe and Visick, } \\
\text { 2008; Valentini and Filloux, 2016), } \\
\text { virulence (Valentini and Filloux, 2019) }\end{array}$ \\
\hline
\end{tabular}

(Continued) 
TABLE 1 | (Continued)

\begin{tabular}{|c|c|c|c|c|}
\hline Nucleotide(s) & Presence in eukaryotes & Exemplary functions in eukaryotes & Presence in bacteria & Exemplary functions in bacteria \\
\hline $3^{\prime}, 5^{\prime}$-c-di-AMP & \multicolumn{2}{|c|}{$\begin{array}{l}\text { - Currently believed to be absent from eukaryotic cells (He } \\
\text { et al., 2020) } \\
\text { - Recognized by human innate immune system (Barker et al., } \\
\text { 2013) }\end{array}$} & $\begin{array}{l}\text { In species of various phyla } \\
\text { (Corrigan and Gründling, } \\
\text { 2013) }\end{array}$ & $\begin{array}{l}\text { - Involvement in several physiological } \\
\text { functions observed (Fahmi et al., 2017) } \\
\text { - Major function: Regulation of cellular } \\
\text { osmotic homeostasis (Stülke and Krüger, } \\
\text { 2020) }\end{array}$ \\
\hline $2^{\prime}, 3^{\prime}$-cGAMP & $\begin{array}{l}\text { Currently believed to only be } \\
\text { present in metazoa (Kranzusch, } \\
\text { 2019) }\end{array}$ & $\begin{array}{l}\text { - Endogenous activator of the innate } \\
\text { immune system leading to type-I } \\
\text { interferon production (Wu et al., 2013; } \\
\text { Zhang et al., 2013) }\end{array}$ & \multicolumn{2}{|c|}{$\begin{array}{l}\text { Isomer containing the atypical } 2^{\prime}{ }^{\prime}{ }^{\prime} \text { phosphodiester linkage } \\
\text { currently believed to be exclusively found in metazoa (Davies } \\
\text { et al., 2012; Ablasser et al., 2013; Diner et al., 2013; Gao et al., } \\
\text { 2013; Li et al., 2019) }\end{array}$} \\
\hline $3^{\prime}, 2^{\prime}$-cGAMP & $\begin{array}{l}\text { Very recently identified in } \\
\text { D. melanogaster; synthesizing } \\
\text { enzymes also conserved in } \\
\text { metazoa (Holleufer et al., 2021; } \\
\text { Slavik et al., 2021) }\end{array}$ & $\begin{array}{l}\text { - Very similar function as } 2^{\prime}, 3^{\prime} \text {-cGAMP as } \\
\text { an endogenous activator of innate } \\
\text { immune response (Holleufer et al., 2021; } \\
\text { Slavik et al., 2021) }\end{array}$ & \multicolumn{2}{|c|}{$\begin{array}{l}\text { Currently no data available on the existence in bacteria; } \\
\text { Presence of the atypical } 2-^{\prime} 5^{\prime} \text { phosphodiester linkage suggest its } \\
\text { absence in bacteria (see } 2^{\prime}, 3^{\prime}-\text {-GAMP above) }\end{array}$} \\
\hline $\mathrm{Ap}_{4} \mathrm{~A}$ & $\begin{array}{l}\text { In a multitude of uni- and } \\
\text { multicellular species (Plesner } \\
\text { and Ottesen, 1980; Flodgaard } \\
\text { and Klenow, 1982; Garrison } \\
\text { and Barnes, 1984; McLennan } \\
\text { and Prescott, 1984) }\end{array}$ & $\begin{array}{l}\text { - Potential stress signaling related } \\
\text { alarmone (Brevet et al., 1985; Baltzinger } \\
\text { et al., 1986; Coste et al., 1987; Garrison } \\
\text { et al., 1989) } \\
\text { - In metazoa: regulatory effects on the } \\
\text { cardiovascular and immune system and } \\
\text { neuronal signal transduction (Vahlensieck } \\
\text { et al., 1999; Miras-Portugal et al., 2003; } \\
\text { Lee et al., 2004) }\end{array}$ & $\begin{array}{l}\text { Synthesizing and } \\
\text { hydrolyzing enzymes } \\
\text { present in various phyla } \\
\text { (Ferguson et al., 2020) }\end{array}$ & $\begin{array}{l}\text { - Potential stress signaling related } \\
\text { alarmone (Lee et al., 1983; Pálfi et al., } \\
\text { 1991; Kimura et al., 2017) } \\
\text { - Cellular development (Nishimura et al., } \\
\text { 1997; Kimura et al., 2017) } \\
\text { - Biofilm formation (Monds et al., 2010) }\end{array}$ \\
\hline \multicolumn{5}{|c|}{ Oligo-nucleotide-based signaling molecules } \\
\hline
\end{tabular}

$3^{\prime}, 5^{\prime}$-cAMP, 3', $5^{\prime}$-cyclic adenosine monophosphate; 3', $5^{\prime}$-cGMP, 3', $5^{\prime}$-cyclic guanosine monophosphate; $3^{\prime}, 5^{\prime}$-cCMP, $3^{\prime}, 5^{\prime}$-cyclic cytidine monophosphate; $3^{\prime}, 5^{\prime}$ cUMP, 3', $5^{\prime}$-cyclic uridine monophosphate; $3^{\prime}, 5^{\prime}$-cIMP, $3^{\prime}, 5^{\prime}$-cyclic inosine monophosphate; 3',5'-cTMP, 3', $5^{\prime}$-cyclic thymidine monophosphate; $3^{\prime}, 5^{\prime}$-cXMP, $3^{\prime}, 5^{\prime}$ cyclic xanthosine monophosphate; $2^{\prime}, 3^{\prime}-c N M P s, 2^{\prime}, 3^{\prime}$-cyclic isomers of nucleotides with $N$ here: adenosine, guanosine, cytidine or uridine; (p)ppGpp, guanosine (penta-)/tetraphosphate; 3', 5'-c-di-GMP, 3', 5'-cyclic diguanosine monophosphate; 3', 5'-c-di-AMP, 3', 5'-cyclic diadenosine monophosphate; 2', 3'-cGAMP, 2', 3'-cyclic guanosine monophosphate-adenosine monophosphate (cyclic $\left.\left[G\left(2^{\prime}, 5^{\prime}\right) p A\left(3^{\prime}, 5^{\prime}\right) p\right]\right) ; 3^{\prime}, 3^{\prime}$-cGAMP, $3^{\prime}, 3^{\prime}$-cyclic guanosine monophosphate-adenosine monophosphate (cyclic $\left[G\left(3^{\prime}, 5^{\prime}\right) p A\left(3^{\prime}, 5^{\prime}\right) p\right]$ ); $3^{\prime}, 2^{\prime}$-cGAMP, $3^{\prime},{ }^{\prime}$-cyclic guanosine monophosphate-adenosine monophosphate (cyclic $\left[G\left(3^{\prime}, 5^{\prime}\right)\right.$ pA $\left.\left(2^{\prime}, 5^{\prime}\right) p\right]$ ); $5^{\prime}$-pGpG, $5^{\prime}$-phosphoguanylyl$3^{\prime}, 5^{\prime}$-guanosine; 5'-pApA, 5'-phosphoadenylyl-3', $5^{\prime}$-adenosine; $A p_{4} A$, diadenosine tetraphosphate; $C O A$, cyclic oligoadenylate (with $n=3-6$ ); CRISPR, Clustered Regularly Interspaced Short Palindromic Repeats; f.i., for instance.

for MW001). Further details on H26 and MW001 are listed in Supplementary Table 1.

\section{Nucleotide Extraction From Haloferax volcanii and Sulfolobus acidocaldarius Cells}

The extraction of nucleotides from total cell pellets of $H$. volcanii and S. acidocaldarius cells was performed as described previously (Spangler et al., 2010; Braun et al., 2019). Briefly, H26 was grown in $340 \mathrm{ml} \mathrm{CAB}+$ uracil, MW001 in $250 \mathrm{ml}$ supplemented Brock + uracil. Samples were taken during exponential growth and at the beginning of the stationary phase. For nucleotide extraction from exponentially growing cultures $25 \mathrm{ml}$ were harvested, for stationary grown cultures $15 \mathrm{ml}$ were harvested. For each nucleotide sample, an additional $2 \mathrm{ml}$ aliquot of each culture was harvested for the determination of the total protein content [bicinchoninic acid (BCA) Protein Assay Macro Kit (Serva)]. Cell pellets were snap-frozen in liquid nitrogen. Unless mentioned otherwise the experiments were performed as three biological replicates with three technical replicates each. The cell pellets were resuspended in $300 \mu \mathrm{l}$ extraction solution [acetonitrile/methanol/water (ultrapure): 2:2:1 (v/v/v)]. Resuspended pellets were incubated on ice for $15 \mathrm{~min}$ followed by a heating step at $95^{\circ} \mathrm{C}$ for $10 \mathrm{~min}$. After cooling on ice, the solution was centrifuged at $21,100 \times g$ for $10 \mathrm{~min}$ at $4^{\circ} \mathrm{C}$. 
The resulting supernatant was transferred to a fresh vial. The extraction was repeated two times (three extraction steps in total) with $200 \mu \mathrm{l}$ fresh extraction solution, omitting the heating step. The supernatants were combined and stored overnight at $-20^{\circ} \mathrm{C}$ to precipitate proteins. To remove precipitates, the samples were centrifuged again $\left(10 \mathrm{~min}, 4^{\circ} \mathrm{C} ; 21,100 \times g\right)$ and the supernatant was transferred to a fresh vial. Final extracts were desiccated using a vacuum concentrator (Eppendorf) at $45^{\circ} \mathrm{C}$.

\section{Nucleotide Extraction From Haloferax volcanii Cell Lysate via Solid Phase Extraction}

Nucleotide extracts from total cell pellets of $H$. volcanii could not be analyzed for their (p)ppGpp content due to certain specific fragmentation patterns of unknown molecular species overlapping with the internal (p)ppGpp standard. Therefore, extraction of (p)ppGpp was performed using a solid phase extraction approach as described previously (Ihara et al., 2015). For solid phase extraction from exponentially growing cultures $15 \mathrm{ml}$ were harvested, for stationary grown cultures $9 \mathrm{ml}$ were harvested. For each sample, an additional $2 \mathrm{ml}$ aliquot of each culture was harvested for the determination of the total protein content (BCA assay). Growth of H26 and time points of sample acquisition were as described above. Cell pellets were snap-frozen in liquid nitrogen and subsequently resuspended in $2 \mathrm{ml}$ ultrapure water on ice. Resuspended pellets were lysed by the addition of formic acid (to a final concentration of $1 \mathrm{M}$ ) and incubated for $1 \mathrm{~h}$ on ice. The cell lysate was mixed with $2 \mathrm{ml}$ ammonium acetate ( $\mathrm{pH} 4.5$ ) and centrifuged for $5 \mathrm{~min}$ at $4^{\circ} \mathrm{C}$ and $3,000 \times g$ to remove cell debris. The lysate was further purified on an OASIS Wax cartridge $1 \mathrm{cc}$ (Waters) using centrifugation steps of $1 \mathrm{~min}$ at $4,300 \times g$ at $4^{\circ} \mathrm{C}$. The cartridge was equilibrated with $1 \mathrm{ml}$ methanol followed by $1 \mathrm{ml}$ ammonium acetate $(\mathrm{pH}$ 4.5 ), the lysate was loaded in four consecutive loading steps of $1 \mathrm{ml}$, the cartridge was washed with $1 \mathrm{ml}$ ammonium acetate $(\mathrm{pH}$ 4.5) followed by $1 \mathrm{ml}$ methanol and the sample was eluted with $1 \mathrm{ml}$ elution solvent [water (ultrapure)/methanol/ammonium hydroxide $(25 \%(\mathrm{w} / \mathrm{v})):$ : $: 2: 1(\mathrm{v} / \mathrm{v} / \mathrm{v})]$. The elution fractions were desiccated using a vacuum concentrator (Eppendorf) at $45^{\circ} \mathrm{C}$.

\section{Quantification of Nucleotides From Cell Extracts by Liquid Chromatography With Tandem Mass Spectrometry}

Desiccated nucleotide extracts were resuspended in $200 \mu \mathrm{l}$ water, centrifuged and diluted 1:2 with the respective standard solution (containing stable isotope labeled nucleotides as well as $100 \mathrm{mg} / \mathrm{ml}$ Tenofovir as internal standards) and analyzed by a LC-MS/MS method.

Cyclic di-nucleotides were analyzed as described previously (Rao et al., 2010; Bähre and Kaever, 2017). Chromatographic separation was performed by reversed phase chromatography on a C18-column (Nucleodur Pyramid C18 $3 \mu 50 \times 3 \mathrm{~mm}$; Macherey-Nagel; Germany), using water containing $10 \mathrm{mM}$ ammonium acetate and $0.1 \%$ acetic acid as eluent $\mathrm{A}$ and pure methanol as eluent $B$, using the following gradient: $0-4$ min $0 \% \mathrm{~B}, 4-7.3 \mathrm{~min} 0-10 \% \mathrm{~B}, 7.3-8.3 \mathrm{~min} 10 \% \mathrm{~B}, 8.3-11 \mathrm{~min}$
$10-30 \% \mathrm{~B}, 11-13 \mathrm{~min} 0 \% \mathrm{~B}$. The flow rate was $600 \mu \mathrm{l} / \mathrm{min}$. Mass spectrometric analysis was performed on a tandem mass spectrometer (API4000; MA, United States) performing selected reaction monitoring (SRM). The mass spectrometer was equipped with an electrospray ionization source (ESI) and ionization was performed in positive mode for all analytes.

Cyclic nucleotides, were analyzed as described previously (Bähre and Kaever, 2014). Chromatographic separation was performed by reversed phase chromatography on a C18-column, using methanol-water [3:97 (v/v)] containing $50 \mathrm{mM}$ ammonium acetate and $0.1 \%(\mathrm{v} / \mathrm{v})$ acetic acid as eluent $\mathrm{A}$ and methanol-water [97:3 (v/v)] containing $50 \mathrm{mM}$ ammonium acetate and $0.1 \%(\mathrm{v} / \mathrm{v})$ acetic acid as eluent $\mathrm{B}$, using the following gradient: $0-5 \mathrm{~min}$ $0-50 \% \mathrm{~B}$ and $5-8 \mathrm{~min} 0 \% \mathrm{~B}$. The flow rate was $500 \mu \mathrm{l} / \mathrm{min}$. Cyclic nucleotides were analyzed on a QTRAP 5500 (Sciex, MA, United States). Ionization was achieved with an ESI in positive mode. In SRM mode $3^{\prime}, 5^{\prime}$-cNMPs and the $2^{\prime}, 3^{\prime}$-cNMPs show the same mass transitions due to their high structural similarity. However, these analytes were clearly identified by their different retention times.

$\mathrm{Ap}_{4} \mathrm{~A}, \mathrm{ppGpp}$, and pppGpp were analyzed as described previously (Schäfer et al., 2020). Chromatographic separation was performed on a Hypercarb column $(30 \times 4.6 \mathrm{~mm}, 5 \mu \mathrm{m}$ particle size; Thermo Fisher, Scientific MA, United States) using $10 \mathrm{mM}$ ammonium acetate $(\mathrm{pH} 10)$ as eluent $\mathrm{A}$ and acetonitril as eluent $\mathrm{B}$, using an $8 \mathrm{~min}$ gradient from 4 to $60 \% \mathrm{~B}$. The flow rate was $600 \mu \mathrm{l} / \mathrm{min}$. All analytes were detected by LC-MS/MS on a QTRAP 5500 (Sciex MA, United States). Ionization of analytes was achieved with an ESI in positive ion mode and SRM was used for analyte detection.

For all used LC-MS/MS methods, the control of the LC and the mass spectrometers as well as data sampling was performed using Analyst software (version 1.7 Sciex, MA, United States). For quantification, calibration curves were created by plotting peak area ratios of the analyte, and the internal standard vs. the nominal concentration of the 10 calibrators. The calibration curve was calculated using quadratic regression and $1 / \times$ weighing.

The measured concentration of each nucleotide was normalized for each cell extract sample to the total protein concentration of the respective sample.

\section{RESULTS AND DISCUSSION}

\section{Haloferax volcanii and Sulfolobus acidocaldarius Cells Grown Under Standard Conditions Contain Several Mono-Nucleotide-Based (Putative) Second Messengers}

We set out to identify nucleotide-based (putative) signaling molecules in the euryarchaeal and crenarchaeal model organisms $H$. volcanii and $S$. acidocaldarius. In a first step, we screened for mono-nucleotide-based (putative) second messengers. The presence of $3^{\prime}, 5^{\prime}$-cAMP in $H$. volcanii cells has been described 35 years ago (Leichtling et al., 1986). Except for $3^{\prime}, 5^{\prime}$-cAMP, 
the presence of other mono-nucleotide-based (putative) second messengers, like other $3^{\prime}, 5^{\prime}$-cyclic nucleotides $\left(3^{\prime}, 5^{\prime}\right.$-cNMPs), $2^{\prime}, 3^{\prime}$-cNMPs or (p)ppGpp, has not been detected in any archaeal species so far. No reports are available on the presence of $3^{\prime}, 5^{\prime}$ cAMP in $S$. acidocaldarius, but the closely related species $S a$. solfataricus has been shown to produce $3^{\prime}, 5^{\prime}$-cAMP (Leichtling et al., 1986), implying that this nucleotide is most likely also present in $S$. acidocaldarius.

H. volcanii strain H26 and S. acidocaldarius strain MW001 were grown under standard laboratory conditions. These cultures were used to obtain cell material from the exponential and stationary growth phases for nucleotide extraction (Supplementary Figure 1). Extraction of nucleotides from the cell extracts followed by LC-MS/MS not only confirmed the presence of $3^{\prime}, 5^{\prime}$-cAMP in these two species (Figures 1A,B) but also revealed that $3^{\prime}, 5^{\prime}$-cGMP, $3^{\prime}, 5^{\prime}$-cCMP and $3^{\prime}, 5^{\prime}$-cUMP are present in $H$. volcanii as well (Figure 1A). These four $3^{\prime}, 5^{\prime}$-cNMPs showed increased levels in exponentially growing $H$. volcanii cells compared to stationary cells (Figure 1A). Similar observations were made for $3^{\prime}, 5^{\prime}$-cAMP in exponentially growing $S$. acidocaldarius cells, which contained higher amounts of this cyclic nucleotide compared to stationary growth (Figure 1B). $3^{\prime}, 5^{\prime}$-cCMP and $3^{\prime}, 5^{\prime}$-cUMP were not detected in any $S$. acidocaldarius sample (Figure 1B), suggesting that these nucleotides, at least under the tested growth conditions, are not synthesized by this crenarchaeon. $3^{\prime}, 5^{\prime}$-cGMP was the only other $3^{\prime}, 5^{\prime}$-cNMP detected in $S$. acidocaldarius (Figure 1B). However, the levels of $3^{\prime}, 5^{\prime}$-cGMP were low in both tested conditions. Five of nine replicates from the stationary culture (originating from three biological replicates with three technical replicates each) contained sufficient amounts of $3^{\prime}, 5^{\prime}$-cGMP for a quantitative analysis. In all other samples from $S$. acidocaldarius (four replicates from stationary cells and all nine replicates from exponentially growing cells), $3^{\prime}, 5^{\prime}$-cGMP could be detected as well, but at levels which did not allow for a valid quantification. Therefore no reliable $3^{\prime}, 5^{\prime}$-cGMP level could be calculated for this crenarchaeon.

With (some) $3^{\prime}, 5^{\prime}$-cNMPs being present in $H$. volcanii and $S$. acidocaldarius the question arises by which enzymes they are produced. Synthesis of $3^{\prime}, 5^{\prime}$-cAMP in vivo is achieved by adenylate cyclases (ACs) of which six different classes (I-VI) are currently known (Khannpnavar et al., 2020). Very few predicted archaeal ACs fall into class III (Bassler et al., 2018) [cluster of orthologous groups (COG) 2114], while the vast majority belongs to class IV (COG1437), which is characterized by a CYTH (CyaB, thiamine triphosphatase) domain. H. volcanii as well as $S$. acidocaldarius each contain a single gene encoding for a putative class IV AC (HVO_1648 and Saci_0718). The S. acidocaldarius gene product of Saci_0718 has recently, however, been demonstrated not to function as a cyclase but as a phosphohydrolase of the triphosphate tunnel metalloenzyme (TTM) family (Vogt et al., 2021). An in this context performed systematic sequence similarity network analysis of the $\mathrm{CYTH}$ superfamily unveiled that actual class IV ACs only account for a small subgroup, which is entirely of bacterial origin (Vogt et al., 2021). This is in accordance with the observation that a $H$. volcanii deletion mutant lacking HVO_1648 has unchanged $3^{\prime}, 5^{\prime}$-cAMP levels (preliminary data). Together, these observations imply that most archaea are likely to synthesize $3^{\prime}, 5^{\prime}$-cAMP with a yet unknown new class of ACs, which is structurally different from the currently established ones.

Enzymes synthesizing $3^{\prime}, 5^{\prime}$-cGMP, called guanylate cyclases, have been characterized from bacteria (Marden et al., 2011; An et al., 2013) and eukaryotes (Kang et al., 2019). Protein BLAST searches using the sequences of the guanylate cyclase domains of such enzymes (Marden et al., 2011; An et al., 2013; Kang et al., 2019) against the translated protein databases of species of the genera Haloferax and Sulfolobus yielded no results with significant similarity. This finding is supported by the fact that the COG2114 (adenylate and guanylate cyclase catalytic domain) neither contains a homolog for $H$. volcanii nor for $S$. acidocaldarius. All these observations might imply that $3^{\prime}, 5^{\prime}$ cGMP in $H$. volcanii and S. acidocaldarius is not generated by a classic guanylate cyclase.

$3^{\prime}, 5^{\prime}$-cCMP and $3^{\prime}, 5^{\prime}$-cUMP were just recently identified to play an important role as signaling molecules in prokaryotic phage-defense systems (Tal et al., 2021). A recently performed phylogenetic analysis of proteins containing pyrimidine cyclase domains revealed that these types of enzymes are also found in few euryarchaeal species (Tal et al., 2021). However, BLAST searches of these identified putative euryarchaeal pyrimidine cyclases in the proteome of $H$. volcanii yielded no hit. The same applies when experimentally characterized bacterial pyrimidine cyclases (Tal et al., 2021) were used as template. This observation might suggest the existence of additional and more distantly to the recently discovered pyrimidine cyclases related types of specific cytidylate/uridylate cyclases. Nevertheless, since guanylate and adenylate cyclases were identified or are assumed to be capable of not only producing their respective intrinsic products but also $3^{\prime}, 5^{\prime}$-cCMP and $3^{\prime}, 5^{\prime}$-cUMP under certain conditions (Beste et al., 2012; Bähre et al., 2014; Seifert, 2017), it is possible that the detected $3^{\prime}, 5^{\prime}$-cCMP and $3^{\prime}, 5^{\prime}$-cUMP originate from a divergent enzymatic activity of these two types of cyclases.

In addition to $3^{\prime}, 5^{\prime}$-cAMP, $3^{\prime}, 5^{\prime}$-cGMP, $3^{\prime}, 5^{\prime}$-cCMP, and $3^{\prime}, 5^{\prime}$ cUMP, the cell extracts from both species were also checked for the presence of $3^{\prime}, 5^{\prime}$-cTMP, $3^{\prime}, 5^{\prime}$-cIMP, and $3^{\prime}, 5^{\prime}$-cXMP, however, none of these cyclic nucleotides could be detected (Table 2). Only very few studies show the presence $3^{\prime}, 5^{\prime}$-cIMP in biological systems (Newton et al., 1998; Chen et al., 2014), with some of these reports called into question when it comes to the specificity of the detection method used (Seifert, 2015). Therefore, it is difficult to speculate whether the absence of $3^{\prime}, 5^{\prime}$-cIMP observed in $H$. volcanii and $S$. acidocaldarius indicates a general absence of this nucleotide or an absence under the standard conditions used in this study. The absence of $3^{\prime}, 5^{\prime}$-cTMP and $3^{\prime}, 5^{\prime}$-cXMP in cell extracts from both model organisms is in line with the fact that these cyclic nucleotides have not been unequivocally identified in any living cell yet.

Additionally to $3^{\prime}, 5^{\prime}$-cNMPs, $H$. volcanii and $S$. acidocaldarius cell extracts were also analyzed for the presence of $2^{\prime}, 3^{\prime}$ cNMPs. All four examined $2^{\prime}, 3^{\prime}$-cNMPs, namely $2^{\prime}, 3^{\prime}$-cAMP, $2^{\prime}, 3^{\prime}$-cGMP, $2^{\prime}, 3^{\prime}$-cCMP and $2^{\prime}, 3^{\prime}$-cUMP, were present in both species in samples from at least one of the two tested growth stages (Figures 2A,B). For $H$. volcanii cell extracts, 
A

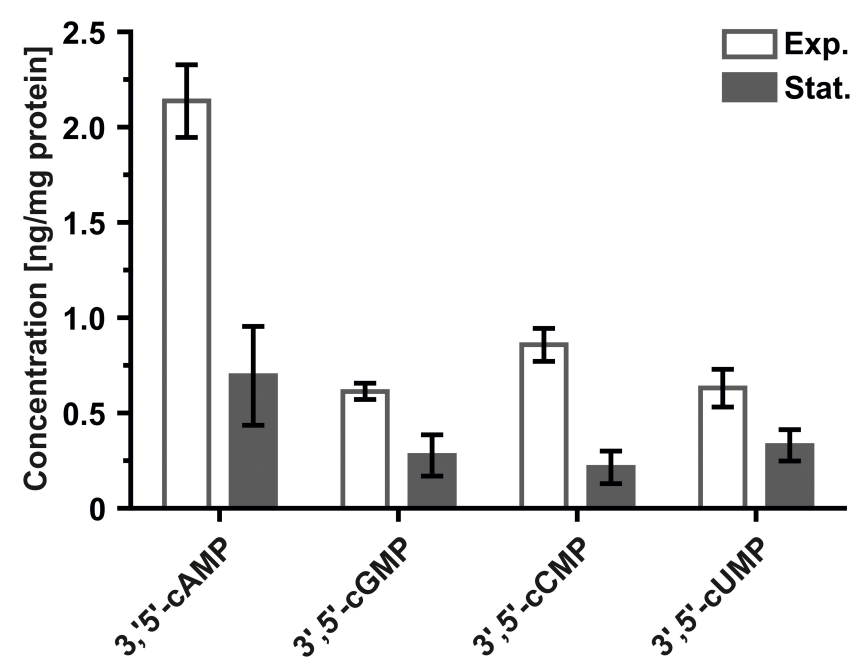

B

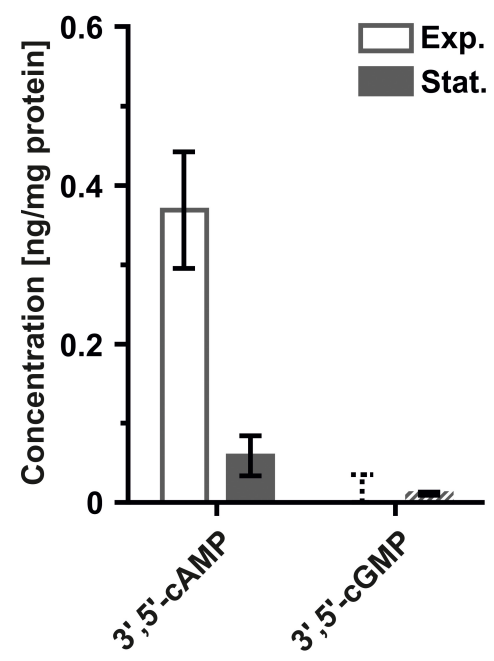

FIGURE 1 | Levels of $3^{\prime}, 5^{\prime}$-cNMPs detected for exponentially and stationary growing (A) H. volcanii H26 and (B) S. acidocaldarius MW001 cells normalized to the protein content of each sample. Values of regular columns represent the mean of three biological replicates. Error bars of regular columns indicate standard deviation of three biological replicates. Dashed columns indicate the presence of one or more technical replicates with measured nucleotide levels below the lowest limit of quantification (LLOQ). Values of dashed columns represent the mean of all technical replicates with nucleotide levels $\geq$ LLOQ. Error bars of dashed columns indicate standard deviation of all technical replicates with nucleotide levels $\geq$ LLOQ. Dashed error bars indicate absence of a single technical replicate with measured nucleotide levels $\geq$ LLOQ. Values of dashed error bars represent the highest calculated value of all analyzed technical replicates with measured nucleotide levels < LLOQ. The exact nucleotide concentrations are summarized in Table 2 (Exp., exponential; Stat., stationary).

TABLE 2 | Summary of measured and detected mono-nucleotide-based (putative) second messengers.

\begin{tabular}{|c|c|c|c|c|}
\hline \multirow{2}{*}{$\frac{\text { Organism }}{\text { Molecule }}$} & \multicolumn{2}{|c|}{ H. volcanii } & \multicolumn{2}{|c|}{ S. acidocaldarius } \\
\hline & $\begin{array}{l}\text { Levels during exponential growth } \\
\text { [ng/mg protein] }\end{array}$ & $\begin{array}{l}\text { Levels during stationary growth } \\
\text { [ng/mg protein] }\end{array}$ & $\begin{array}{l}\text { Levels during exponential growth } \\
\text { [ng/mg protein] }\end{array}$ & $\begin{array}{l}\text { Levels during stationary growth } \\
\text { [ng/mg protein] }\end{array}$ \\
\hline $3^{\prime}, 5^{\prime}-c A M P$ & $2.14 \pm 0.19$ & $0.70 \pm 0.26$ & $0.37 \pm 0.07$ & $0.06 \pm 0.03$ \\
\hline $3^{\prime}, 5^{\prime}-c G M P$ & $0.61 \pm 0.04$ & $0.28 \pm 0.11$ & $\geq 0$ & $\leq 0.01 \pm 0.002$ \\
\hline $3^{\prime}, 5^{\prime}-c C M P$ & $0.86 \pm 0.09$ & $0.22 \pm 0.08$ & n.d. & n.d. \\
\hline $3^{\prime}, 5^{\prime}-c U M P$ & $0.63 \pm 0.10$ & $0.33 \pm 0.08$ & n.d. & n.d. \\
\hline $3^{\prime}, 5^{\prime}-c T M P$ & n.d. & n.d. & n.d. & n.d. \\
\hline $3^{\prime}, 5^{\prime}-c / M P$ & n.d. & n.d. & n.d. & n.d. \\
\hline $3^{\prime}, 5^{\prime}-c X M P$ & n.d. & n.d. & n.d. & n.d. \\
\hline $2^{\prime}, 3^{\prime}-C A M P$ & $50.03 \pm 3.70$ & $32.23 \pm 5.86$ & $1.65 \pm 0.16$ & $1.13 \pm 0.31$ \\
\hline $2^{\prime}, 3^{\prime}-c G M P$ & $36.33 \pm 2.66$ & $21.91 \pm 4.80$ & $0.92 \pm 0.10$ & $0.85 \pm 0.25$ \\
\hline $2^{\prime}, 3^{\prime}-c C M P$ & $25.21 \pm 1.99$ & $18.72 \pm 3.02$ & $0.36 \pm 0.18$ & $0.53 \pm 0.15$ \\
\hline $2^{\prime}, 3^{\prime}-c U M P$ & $0.84 \pm 0.19$ & $0.66 \pm 0.17$ & n.d. & $\leq 0.04 \pm 0.006$ \\
\hline ppGpp & n.d. & n.d. & n.d. & n.d. \\
\hline pppGpp & n.d. & n.d. & n.d. & n.d. \\
\hline
\end{tabular}

( \pm , gives standard deviation; n.d., not detectable; $\leq$, average of all technical replicates $\geq L L O Q ; \geq 0$, nucleotide detected but all technical replicates < LLOQ).

the measured concentrations of $2^{\prime}, 3^{\prime}$-cAMP, $2^{\prime}, 3^{\prime}$-cGMP, and $2^{\prime}, 3^{\prime}$-cCMP (Figure 2A) were much higher than the ones of the corresponding $3^{\prime}, 5^{\prime}$-isomer (Figure 1A). Only $2^{\prime}, 3^{\prime}$ cUMP was present at concentrations similar to $3^{\prime}, 5^{\prime}$-cUMP. Similar to the $3^{\prime}, 5^{\prime}$-cNMPs, the concentrations of $2^{\prime}, 3^{\prime}$-cNMPs in $H$. volcanii generally increased during exponential growth (Figure 2A). In $S$. acidocaldarius extracts, $2^{\prime}, 3^{\prime}$-cNMP levels were in the same range for exponential and stationary growth (Figure 2B). Similarly, to what was observed for the $2^{\prime}, 3^{\prime}$-cUMP levels of $H$. volcanii, levels of this $2^{\prime}, 3^{\prime}$-cyclic nucleotide in $S$. acidocaldarius were also considerably lower in comparison to the other three $2^{\prime}, 3^{\prime}$-cNMPs. Of all stationary samples, only three technical replicates (out of nine in total) contained quantifiable amounts of $2^{\prime}, 3^{\prime}$-cUMP, whereas samples of exponentially growing $S$. acidocaldarius cells did not contain any $2^{\prime}, 3^{\prime}$-cUMP. Production of the detected $2^{\prime}, 3^{\prime}$-cNMPs in both species has most likely to be linked to the process of RNA-degradation, a major source of $2^{\prime}, 3^{\prime}$-cNMPs in eukaryotes and bacteria 
(Thompson et al., 1994; Fontaine et al., 2018), and/or to the activity of homologs of certain RNA cyclases/ligases, which are also known to form $2^{\prime}, 3^{\prime}$-cyclic phosphates at the $3^{\prime}$-ends of RNAs (Shigematsu et al., 2018). As currently no distinct function as second messenger is ascribed to any $2^{\prime}, 3^{\prime}$-cNMP it appears likely that they are not used as such in $H$. volcanii and $S$. acidocaldarius as well. Still, it also cannot be excluded that they may act in some yet to be discovered signaling network.

Next to $3^{\prime}, 5^{\prime}$-cNMPs and $2^{\prime}, 3^{\prime}$-cNMPs, the cell extracts were also analyzed for the presence of the alarmone ppGpp and its precursor pppGpp. Analysis of extracts from S. acidocaldarius did not detect any (p)ppGpp at the tested conditions (Table 2). Since cell extracts of $H$. volcanii contained substances that interfered with the (p)ppGpp internal standard signal, an alternative solid phase extraction protocol was used (see section "Materials and Methods"). For these extracts the internal (p)ppGpp standard signal was unaffected and the corresponding measurements revealed that neither ppGpp nor pppGpp was present in the $H$. volcanii samples (Table 2). These observations are in accordance with former studies examining the occurrence of (p)ppGpp in both species which showed that this alarmone was not produced, even when cells were subjected to stress factors such as starvation (Scoarughi et al., 1995; Cellini et al., 2004). In line with this, a study on the distribution of (p)ppGpp synthetases and hydrolases across the tree of life suggests that $H$. volcanii and $S$. acidocaldarius do not contain any of these enzymes (COG0317 contains no hit for both organisms) and that they are in general only very rarely found in archaea (Atkinson et al., 2011).

\section{Cyclic Diadenosine Monophosphate, 5'-Phosphoadenylyl-3', $5^{\prime}$-Adenosine, and Diadenosine Tetraphosphate Are the Only Di-Nucleotide-Based (Putative) Second Messengers Measured in at Least One of the Two Archaeal Model Organisms}

In a second step, we screened for di-nucleotide-based (putative) second messengers. The only di-nucleotide-based second messenger detected in any archaeon so far is $3^{\prime}, 5^{\prime}$-c-di-AMP. It was recently shown to be produced in the euryarchaeon $H$. volcanii by the corresponding di-adenylate cyclase $\mathrm{DacZ}$ and osmoregulation had been implicated as a major function of this nucleotide (Braun et al., 2019). Extraction of nucleotides from the cell extracts followed by LC-MS/MS confirmed the presence of $3^{\prime}, 5^{\prime}$-c-di-AMP during both the exponential and the stationary phase at concentrations similar to what was detected previously (Braun et al., 2019; Figure 3A). In contrast to $H$. volcanii, $S$. acidocaldarius cell extracts generated in this study did not contain any $3^{\prime}, 5^{\prime}$-c-di-AMP. A protein BLAST search using the sequences of an established bacterial (Rosenberg et al., 2015) and an archaeal (Braun et al., 2019) di-adenylate cyclases against the proteome of $S$. acidocaldarius yielded no significant hits. These observations are consistent with previous bioinformatical analyses showing that proteins containing the $3^{\prime}, 5^{\prime}$-c-di-AMP synthesizing diadenylate cyclase (DAC)-domain (COG1624) are absent in crenarchaeota, while being frequently found in euryarchaeota (Römling, 2008; Witte et al., 2008; He et al., 2020). This suggests that $3^{\prime}, 5^{\prime}$-c-di-AMP is likely to be used as second messenger by many euryarchaea, whereas crenarchaea do not seem to utilize this signaling nucleotide.

With $3^{\prime}, 5^{\prime}$-c-di-AMP being present in $H$. volcanii, it was not surprising that its (intermediate) degradation product $5^{\prime}$ pApA, was also found in this euryarchaeon (Figure 3A). The concentration of $5^{\prime}$-pApA was, however, significantly lower than the concentration of $3^{\prime}, 5^{\prime}$-c-di-AMP. Especially samples from exponentially growing cultures contained only low amounts of $5^{\prime}$-pApA. Although all nine replicates of exponential cultures included $5^{\prime}$-pApA, only two of them contained sufficient amounts for a quantitative analysis. These very low levels of $5^{\prime}$-pApA suggests that most of this linear di-nucleotide in $H$. volcanii is further degraded to $5^{\prime}$-AMP, the final degradation product of $3^{\prime}, 5^{\prime}$-c-di-AMP (Commichau et al., 2019). The phosphodiesterases which are degrading $3^{\prime}, 5^{\prime}$-c-di-AMP and/or $5^{\prime}$-pApA in $H$. volcanii are currently unknown, as well as a potential function of $5^{\prime}$-pApA as second messenger. Samples from exponentially growing $S$. acidocaldarius cells did not exhibit any $5^{\prime}$-pApA. Yet, most samples (eight of nine replicates) from stationary $S$. acidocaldarius cultures included minor amounts of $5^{\prime}$-pApA (Figure 3B). However, as these amounts were in all samples below the quantification limit no valid average $5^{\prime}$ pApA level could be calculated. As $S$. acidocaldarius does not contain any $3^{\prime}, 5^{\prime}$-c-di-AMP these minor amounts of $5^{\prime}$-pApA do certainly not originate from the degradation of $3^{\prime}, 5^{\prime}$-c-diAMP. As the genome of $S$. acidocaldarius has an $\mathrm{A}+\mathrm{T}$ content of $63 \%$ (Chen et al., 2005) it appears possible that the detected molecules of $5^{\prime}$-pApA are intermediate fragments from degraded genomic DNA.

Diadenosine tetraphosphate $\left(\mathrm{Ap}_{4} \mathrm{~A}\right)$, which was shown in several bacteria to function as an stress induced second messenger (Lee et al., 1983; Pálfi et al., 1991; Kimura et al., 2017; Ferguson et al., 2020), could be detected in cell extracts from both archaeal model organisms (Figures 3A,B). For both species, levels of $\mathrm{Ap}_{4} \mathrm{~A}$ were higher during exponential growth. However, samples from exponentially growing $H$. volcanii cells exhibited a quite broad fluctuation among individual technical replicates and among the biological replicates, with some samples even exhibiting a complete absence of $\mathrm{Ap}_{4} \mathrm{~A}$ (Figure 3A). Intriguingly, $\mathrm{Ap}_{4} \mathrm{~A}$ levels in exponentially growing $S$. acidocaldarius cells were the highest of all putative nucleotide-based second messengers detected in this study (Figure 3B). Noteworthy, exponential samples from $S$. acidocaldarius did not show a similar broad fluctuation for their $\mathrm{Ap}_{4} \mathrm{~A}$ levels as observed for exponential samples from $H$. volcanii. The 16-fold difference between $\mathrm{Ap}_{4} \mathrm{~A}$ levels in $S$. acidocaldarius cells during exponential growth and the stationary phase is the largest difference that was observed between the two phases within this study. Whether $A_{4} \mathrm{~A}$ is actually used in a second messenger context and what possible biological functions this di-nucleotide could have in $H$. volcanii and $S$. acidocaldarius is currently not known. The observed differences between exponential and stationary growth phases as well as the high amounts of $\mathrm{Ap}_{4} \mathrm{~A}$ specifically produced by 
A

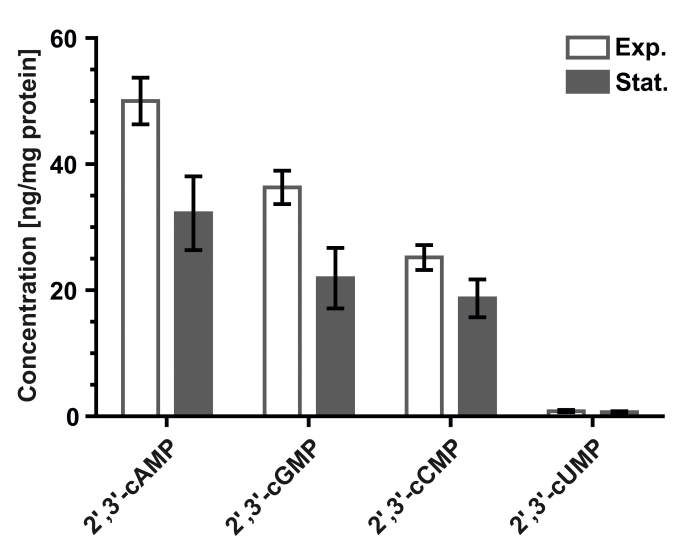

B

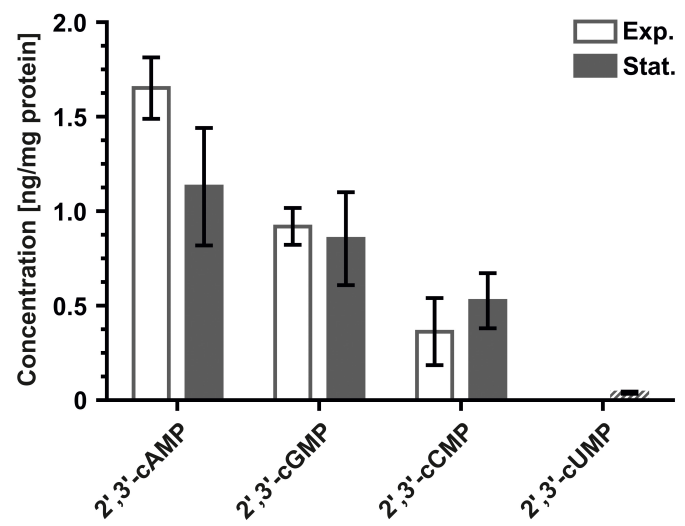

FIGURE 2 | Levels of $2^{\prime}, 3^{\prime}$-cNMPs detected for exponentially and stationary growing (A) H. volcanii H26 and (B) S. acidocaldarius MW001 cells normalized to the protein content of each sample. Values of regular columns represent the mean of three biological replicates. Error bars of regular columns indicate standard deviation of three biological replicates. Dashed columns indicate presence of one or more technical replicates with measured nucleotide levels below the lowest limit of quantification (LLOQ). Values of dashed columns represent the mean of all technical replicates with nucleotide levels $\geq$ LLOQ. Error bars of dashed columns indicate standard deviation of all technical replicates with nucleotide levels $\geq$ LLOQ. The exact nucleotide concentrations are summarized in Table 2 (Exp., exponential; Stat., stationary).
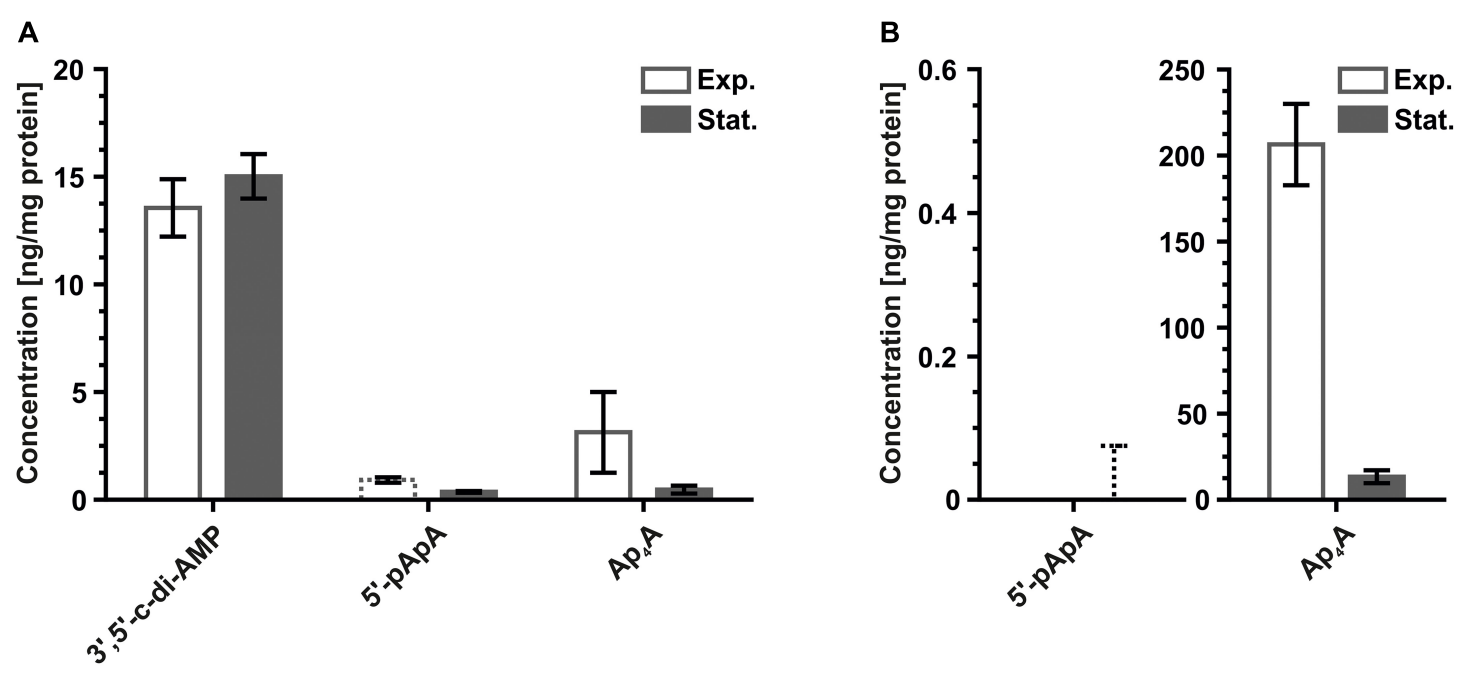

FIGURE 3 | Levels of di-nucleotide-based (putative) second messengers detected for exponentially and stationary growing (A) H. volcanii H26 and

(B) S. acidocaldarius MW001 cells normalized to the protein content of each sample. Values of regular columns represent the mean of three biological replicates. Error bars of regular columns indicate standard deviation of three biological replicates. Dashed columns indicate presence of one or more technical replicates with measured nucleotide levels below the lowest limit of quantification (LLOQ). Values of dashed columns represent the mean of all technical replicates with nucleotide levels $\geq$ LLOQ. Error bars of dashed columns indicate standard deviation of all technical replicates with nucleotide levels $>$ LLOQ. Dashed error bars indicate absence of a single technical replicate with measured nucleotide levels $\geq$ LLOQ. Values of dashed error bars represent the highest calculated value of all analyzed technical replicates with measured nucleotide levels < LLOQ. The exact nucleotide concentrations are summarized in Table $\mathbf{3}$ (Exp., exponential; Stat., stationary).

exponentially growing $S$. acidocaldarius cells imply a general physiological relevance of this di-nucleotide. Noteworthy, bioinformatical identification of any $\mathrm{Ap}_{4} \mathrm{~A}$ synthesizing enzyme in $S$. acidocaldarius and $H$. volcanii is particularly complicated as a broad variety of aminoacyl-tRNA synthetases and also other enzymes like, for example, DNA and RNA ligases, are known to be capable of forming this di-nucleotide (Fraga and Fontes, 2011; Ferguson et al., 2020).
Interestingly, the very well established bacterial second messenger $3^{\prime}, 5^{\prime}$-c-di-GMP and its (intermediate) degradation product $5^{\prime}$-pGpG were not detected in the cell extracts of $H$. volcanii and $S$. acidocaldarius. This suggests that this cyclic di-nucleotide is, unlike to various bacteria, not a key regulatory molecule in these two species. Indeed, a protein BLAST search using the GGDEF-domain, the domain responsible for $3^{\prime}, 5^{\prime}$-cdi-GMP formation (Paul et al., 2004), of a di-guanylate cyclase 
TABLE 3 | Summary of measured and detected di-nucleotide-based (putative) second messengers.

\begin{tabular}{|c|c|c|c|c|}
\hline \multirow{2}{*}{$\begin{array}{l}\text { Organism } \\
\text { Molecule }\end{array}$} & \multicolumn{2}{|c|}{ H. volcanii } & \multicolumn{2}{|c|}{ S. acidocaldarius } \\
\hline & $\begin{array}{l}\text { Levels during exponential growth } \\
\text { [ng/mg protein] }\end{array}$ & $\begin{array}{l}\text { Levels during stationary growth } \\
\text { [ng/mg protein] }\end{array}$ & $\begin{array}{l}\text { Levels during exponential growth } \\
\text { [ng/mg protein] }\end{array}$ & $\begin{array}{l}\text { Levels during stationary growth } \\
\text { [ng/mg protein] }\end{array}$ \\
\hline $3^{\prime}, 5^{\prime}-c-d i-G M P$ & n.d. & n.d. & n.d. & n.d. \\
\hline $3^{\prime}, 5^{\prime}-c-d i-A M P$ & $13.56 \pm 1.34$ & $15.02 \pm 1.03$ & n.d. & n.d. \\
\hline $5^{\prime}-p G p G$ & n.d. & n.d. & n.d. & n.d. \\
\hline $5^{\prime}-p A p A$ & $\leq 0.92 \pm 0.13$ & $0.37 \pm 0.04$ & n.d. & $\geq 0$ \\
\hline $2^{\prime}, 3^{\prime}-c G A M P$ & n.d. & n.d. & n.d. & n.d. \\
\hline $3^{\prime}, 3^{\prime}-c G A M P$ & n.d. & n.d. & n.d. & n.d. \\
\hline $3^{\prime}, 2^{\prime}-c G A M P$ & n.d. & n.d. & n.d. & n.d. \\
\hline$A p_{4} A$ & $3.14 \pm 1.88$ & $0.48 \pm 0.18$ & $206.51 \pm 26.61$ & $13.40 \pm 3.77$ \\
\hline
\end{tabular}

( \pm , gives standard deviation; n.d., not detectable; $\leq$, average of all technical replicates $\geq L L O Q ; \geq 0$, nucleotide detected but all technical replicates < LLOQ).

from E. coli (Ryjenkov et al., 2005) against the genera Haloferax and Sulfolobus yielded no hits for the genus Sulfolobus and only three hits for the genus Haloferax, of which only one contained the complete GGDEF-motive (hypothetical protein; overall query cover: $40 \%$, percent identity: $38.89 \%$ ). This is in agreement with previous bioinformatical analyses which showed that not only proteins with a GGDEF-domain are almost completely absent in archaea, but also proteins with all other domains associated with $3^{\prime}, 5^{\prime}$-c-di-GMP signaling (e.g., EAL- or PilZdomain) (Römling et al., 2013). Nevertheless, an analogous BLAST search against the entire domain of archaea yielded more than 300 hits of putative GGDEF-domain containing enzymes with many of them being predicted to belong to species of the recently discovered Asgard- and DPANN-superphyla. This suggests that $3^{\prime}, 5^{\prime}$-c-di-GMP might not entirely be absent in the archaeal domain of life.

In addition to $3^{\prime}, 5^{\prime}$-c-di-GMP and $5^{\prime}$-pGpG, cell extracts were also analyzed for the presence of the eukaryotic dinucleotide-based second messengers $2^{\prime}, 3^{\prime}$-cGAMP and $3^{\prime}, 2^{\prime}$ cGAMP and their bacterial analog $3^{\prime}, 3^{\prime}$-cGAMP. None of these three isomers could be detected. The absence of $2^{\prime}, 3^{\prime}$-cGAMP in $H$. volcanii and $S$. acidocaldarius fits with the current idea of $2^{\prime}, 3^{\prime}$-cGAMP only being present in metazoa (Kranzusch et al., 2015). The recently discovered isomer $3^{\prime}, 2^{\prime}$-cGAMP was also not detected in any sample. As this isomer also contains an atypical $2-^{\prime} 5^{\prime}$ phosphodiester linkage it appears very likely that it is also only produced by metazoa. The fact that $3^{\prime}, 3^{\prime}$-cGAMP is absent in both species might suggest that both do not use any of the prokaryotic anti-phage defense mechanisms, which have been previously linked to bacterial 3',3-'cGAMP production (Severin et al., 2018; Cohen et al., 2019). This idea is also supported by a complete lack of proteins in the genera of Haloferax and Sulfolobus sharing significant similarities with so far characterized bacterial cyclic GMP-AMP synthases (cGASs) (BLAST search using two characterized bacterial cGASs; Davies et al., 2012; Li et al., 2019). A look at the COGs for both, bacterial (ENOG5028K9C) and metazoan (KOG3963), cGASs unveils that each of them is specific for its respective domain and that they do not root in a common COG which would also include any archaeon.

\section{Cyclic Tetra-AMP Could Not Be Detected in Haloferax volcanii and Sulfolobus acidocaldarius Cell Extracts}

Only a few cyclic oligo-nucleotide-based second messengers have been identified. An example of this is c-tetra-AMP $(n=4)$, which is known to occur, alongside with other isomers of cyclic oligo adenylate $(n=3-6)$ (cOA), in some crenarchaeal species, such as $\mathrm{Sa}$. solfataricus, a species closely related to $\mathrm{S}$. acidocaldarius (Rouillon et al., 2018). There, cOA was shown to be involved in type III CRISPR system mediated immunity (Kazlauskiene et al., 2017; Niewoehner et al., 2017; Rouillon et al., 2018). No c-tetraAMP could be detected in any of the samples prepared for this study. As $S$. acidocaldarius encodes a functional type III CRISPR system that contains a Cas10 subunit (Zink et al., 2021) detection of c-tetra-AMP in extracts from this species could have been expected. However, as the cells in this study were not challenged with any invading virus it is plausible that the observed lack of c-tetra-AMP originates from the type III CRISPR system of $S$. acidocaldarius being inactive at the tested conditions. $H$. volcanii and other euryarchaea of the order Halobacteriales contain type I, but lack type III CRISPR systems (Maier et al., 2019), which certainly explains the absence of c-tetra-AMP (and thereby most likely the absence of cOA in general) in $H$. volcanii.

\section{CONCLUDING REMARK}

The results of this study represent the first screening of cell extracts from an euryarchaeal and a crenarchaeal species for a multitude of currently known (and established) nucleotide-based second messengers using a modern and highly sensitive mass spectrometry method. It gives a comprehensive overview on a broad spectrum of (potential) small signaling molecules which are present in the archaeal model organisms $H$. volcanii and $S$. acidocaldarius under standard growth and experimental conditions. The function of second messengers includes rapid variations within their levels depending on changing environmental conditions. It thus appears reasonable that the here measured nucleotide levels might considerably change when different cultivation methods/circumstances are used. Even 
the appearance of a nucleotide species totally absent here (or vice versa) appears then possible. Determining the nucleotide levels in such differentiating growth experiments could help to elucidate the functions of several of the here reported (putative) second messengers in $H$. volcanii and $S$. acidocaldarius, and thereby also in archaea in more general.

\section{DATA AVAILABILITY STATEMENT}

The raw data supporting the conclusions of this article will be made available by the authors, upon request.

\section{AUTHOR CONTRIBUTIONS}

FB designed the experiments and analyzed data under supervision from S-VA. FB performed the growth of $H$. volcanii and the nucleotide extractions. AR performed the growth of S. acidocaldarius. HB and RS supervised LC-MS/MS nucleotide measurements. FB wrote the manuscript with input from $\mathrm{HB}$, AR, RS, and S-VA. All authors contributed to the article and approved the submitted version.

\section{REFERENCES}

Ablasser, A., Goldeck, M., Cavlar, T., Deimling, T., Witte, G., Röhl, I., et al. (2013). cGAS produces a $2^{\prime}-5^{\prime}$-linked cyclic dinucleotide second messenger that activates STING. Nature 498, 380-384. doi: 10.1038/nature12306

Allers, T., Ngo, H.-P., Mevarech, M., and Lloyd, R. G. (2004). Development of additional selectable markers for the halophilic archaeon Haloferax volcanii based on the leuB and trpA genes. Appl. Environ. Microbiol. 70, 943-953. doi: 10.1128/AEM.70.2.943-953.2004

An, S.-Q., Chin, K.-H., Febrer, M., McCarthy, Y., Yang, J.-G., Liu, C.-L., et al. (2013). A cyclic GMP-dependent signalling pathway regulates bacterial phytopathogenesis. EMBO J. 32, 2430-2438. doi: 10.1038/emboj.2013.165

Anderson, T. R. (1982). Cyclic cytidine $3^{\prime}, 5^{\prime}$-monophosphate (cCMP) in cell regulation. Mol. Cell. Endocrinol. 28, 373-385. doi: 10.1016/0303-7207(82) 90134- 4

Atkinson, G. C., Tenson, T., and Hauryliuk, V. (2011). The RelA/SpoT homolog (RSH) superfamily: distribution and functional evolution of ppGpp synthetases and hydrolases across the tree of life. PLoS One 6:e23479. doi: 10.1371/journal. pone.0023479

Bähre, H., Danker, K. Y., Stasch, J.-P., Kaever, V., and Seifert, R. (2014). Nucleotidyl cyclase activity of soluble guanylyl cyclase in intact cells. Biochem. Biophys. Res. Commun. 443, 1195-1199.

Bähre, H., Hartwig, C., Munder, A., Wolter, S., Stelzer, T., Schirmer, B., et al. (2015). cCMP and cUMP occur in vivo. Biochem. Biophys. Res. Commun. 460, 909-914. doi: $10.1016 /$ j.bbrc.2015.03.115

Bähre, H., and Kaever, V. (2014). Measurement of $2^{\prime}, 3^{\prime}$-cyclic nucleotides by liquid chromatography-tandem mass spectrometry in cells. J. Chromatogr. $B$ Analyt. Technol. Biomed. Life Sci. 964, 208-211. doi: 10.1016/j.jchromb.2014. 02.046

Bähre, H., and Kaever, V. (2017). Identification and Quantification of Cyclic Di-Guanosine Monophosphate and Its Linear Metabolites by Reversed-Phase LC-MS/MS. Methods Mol. Biol. 1657, 45-58. doi: 10.1007/978-1-4939-72 40-1_5

Baltzinger, M., Ebel, J. P., and Remy, P. (1986). Accumulation of dinucleoside polyphosphates in Saccharomyces cerevisiae under stress conditions. High levels are associated with cell death. Biochimie 68, 1231-1236. doi: 10.1016/ s0300-9084(86)80069-4

\section{FUNDING}

This work was supported by the Deutsche Forschungsgemeinschaft (DFG) within the scope of the SPP 1879: Nucleotide Second Messenger Signaling in Bacteria. The article processing charge was funded by the Baden-Württemberg Ministry of Science, Research and Art and the University of Freiburg in the funding programme Open Access Publishing.

\section{ACKNOWLEDGMENTS}

We thank Annette Garbe, Niklas Rieck and the whole staff of the ZFA Metabolomics for the performance of nucleotide mass spectrometry measurements and their technical assistance. We also thank Chris van der Does for critically reading the manuscript.

\section{SUPPLEMENTARY MATERIAL}

The Supplementary Material for this article can be found online at: https://www.frontiersin.org/articles/10.3389/fmicb. 2021.779012/full\#supplementary-material

Barker, J. R., Koestler, B. J., Carpenter, V. K., Burdette, D. L., Waters, C. M., Vance, R. E., et al. (2013). STING-dependent recognition of cyclic di-AMP mediates type I interferon responses during Chlamydia trachomatis infection. mBio 4, e00018-13. doi: 10.1128/mBio.00018-13

Bassler, J., Schultz, J. E., and Lupas, A. N. (2018). Adenylate cyclases: receivers, transducers, and generators of signals. Cell. Signal. 46, 135-144. doi: 10.1016/j. cellsig.2018.03.002

Battesti, A., and Bouveret, E. (2006). Acyl carrier protein/SpoT interaction, the switch linking SpoT-dependent stress response to fatty acid metabolism. Mol. Microbiol. 62, 1048-1063. doi: 10.1111/j.1365-2958.2006.05442.x

Baumann, A., Lange, C., and Soppa, J. (2007). Transcriptome changes and cAMP oscillations in an archaeal cell cycle. BMC Cell Biol. 8:21. doi: 10.1186/14712121-8-21

Beauclerk, A. A., Hummel, H., Holmes, D. J., Böck, A., and Cundliffe, E. (1985). Studies of the GTPase domain of archaebacterial ribosomes. Eur. J. Biochem. 151, 245-255. doi: 10.1111/j.1432-1033.1985.tb09095.x

Beckert, U., Wolter, S., Hartwig, C., Bähre, H., Kaever, V., Ladant, D., et al. (2014). ExoY from Pseudomonas aeruginosa is a nucleotidyl cyclase with preference for cGMP and cUMP formation. Biochem. Biophys. Res. Commun. 450, 870-874. doi: 10.1016/j.bbrc.2014.06.088

Berthet, J., Rall, T. W., and Sutherland, E. W. (1957). The relationship of epinephrine and glucagon to liver phosphorylase. IV. Effect of epinephrine and glucagon on the reactivation of phosphorylase in liver homogenates. J. Biol. Chem. 224, 463-475. doi: 10.1016/s0021-9258(18)65045-8

Beste, K. Y., Burhenne, H., Kaever, V., Stasch, J.-P., and Seifert, R. (2012). Nucleotidyl cyclase activity of soluble guanylyl cyclase $\alpha 1 \beta 1$. Biochemistry 51 , 194-204. doi: 10.1021/bi201259y

Beste, K. Y., and Seifert, R. (2013). cCMP, cUMP, cTMP, cIMP and cXMP as possible second messengers: development of a hypothesis based on studies with soluble guanylyl cyclase $\alpha(1) \beta(1)$. Biol. Chem. 394, 261-270. doi: 10.1515/hsz-20120282

Blanco, E., Fortunato, S., Viggiano, L., and de Pinto, M. C. (2020). Cyclic AMP: a Polyhedral Signalling Molecule in Plants. Int. J. Mol. Sci. 21:4862. doi: 10.3390/ ijms21144862

Bloch, A., Dutschman, G., and Maue, R. (1974). Cytidine 3',5'-monophosphate (cyclic CMP). II. Initiation of leukemia L-1210 cell growth in vitro. Biochem. Biophys. Res. Commun. 59, 955-959. doi: 10.1016/s0006-291x(74)80072-0 
Bordeleau, E., Oberc, C., Ameen, E., da Silva, A. M., and Yan, H. (2014). Identification of cytidine $2^{\prime}, 3^{\prime}$-cyclic monophosphate and uridine $2^{\prime}, 3^{\prime}$-cyclic monophosphate in Pseudomonas fluorescens pfo-1 culture. Bioorg. Med. Chem. Lett. 24, 4520-4522. doi: 10.1016/j.bmcl.2014.07.080

Botsford, J. L., and Harman, J. G. (1992). Cyclic AMP in prokaryotes. Microbiol. Rev. 56, 100-122.

Bowman, L., Zeden, M. S., Schuster, C. F., Kaever, V., and Gründling, A. (2016). New Insights into the Cyclic Di-adenosine Monophosphate (c-di-AMP) Degradation Pathway and the Requirement of the Cyclic Dinucleotide for Acid Stress Resistance in Staphylococcus aureus. J. Biol. Chem. 291, 26970-26986. doi: 10.1074/jbc.M116.747709

Braun, F., Thomalla, L., Does, C., Quax, T. E. F., Allers, T., Kaever, V., et al. (2019). Cyclic nucleotides in archaea: cyclic di-AMP in the archaeon Haloferax volcanii and its putative role. Microbiologyopen 8:e00829. doi: 10.1002/mbo3.829

Brevet, A., Plateau, P., Best-Belpomme, M., and Blanquet, S. (1985). Variation of Ap4A and other dinucleoside polyphosphates in stressed Drosophila cells. J. Biol. Chem. 260, 15566-15570. doi: 10.1016/s0021-9258(17)36294-4

Brock, T. D., Brock, K. M., Belly, R. T., and Weiss, R. L. (1972). Sulfolobus: a new genus of sulfur-oxidizing bacteria living at low $\mathrm{pH}$ and high temperature. Arch. Mikrobiol. 84, 54-68. doi: 10.1007/BF00408082

Burdette, D. L., Monroe, K. M., Sotelo-Troha, K., Iwig, J. S., Eckert, B., Hyodo, M., et al. (2011). STING is a direct innate immune sensor of cyclic di-GMP. Nature 478, 515-518. doi: 10.1038/nature10429

Burhenne, H., Beste, K., Spangler, C., Voigt, U., Kaever, V., and Seifert, R. (2011). Determination of cytidine $3^{\prime}, 5^{\prime}$-cyclic monophosphate and uridine $3^{\prime}, 5^{\prime}$-cyclic monophosphate in mammalian cell systems and in human urine by high performance liquid chromatography/mass spectrometry. Naunyn. Schmiedebergs. Arch. Pharmacol. 383:P096.

Cadoret, J.-C., Rousseau, B., Perewoska, I., Sicora, C., Cheregi, O., Vass, I., et al. (2005). Cyclic nucleotides, the photosynthetic apparatus and response to a UVB stress in the Cyanobacterium Synechocystis sp. PCC 6803. J. Biol. Chem. 280, 33935-33944. doi: 10.1074/jbc.M503153200

Cashel, M., and Gallant, J. (1969). Two compounds implicated in the function of the RC gene of Escherichia coli. Nature 221, 838-841. doi: 10.1038/221838a0

Cellini, A., Scoarughi, G. L., Poggiali, P., Santino, I., Sessa, R., Donini, P., et al. (2004). Stringent control in the archaeal genus Sulfolobus. Res. Microbiol. 155, 98-104. doi: 10.1016/j.resmic.2003.11.006

Chen, L., Brügger, K., Skovgaard, M., Redder, P., She, Q., Torarinsson, E., et al. (2005). The genome of Sulfolobus acidocaldarius, a model organism of the Crenarchaeota. J. Bacteriol. 187, 4992-4999. doi: 10.1128/jb.187.14.4992-4999. 2005

Chen, Z., and Schaap, P. (2012). The prokaryote messenger c-di-GMP triggers stalk cell differentiation in Dictyostelium. Nature 488, 680-683. doi: 10.1038/ nature11313

Chen, Z., Zhang, X., Ying, L., Dou, D., Li, Y., Bai, Y., et al. (2014). cIMP synthesized by sGC as a mediator of hypoxic contraction of coronary arteries. Am. J. Physiol. Heart Circ. Physiol. 307, 328-336. doi: 10.1152/ajpheart.00132.2014

Cimmino, C., Scoarughi, G. L., and Donini, P. (1993). Stringency and relaxation among the halobacteria. J. Bacteriol. 175, 6659-6662. doi: 10.1128/jb.175.20. 6659-6662.1993

Clapham, D. E. (2007). Calcium Signaling. Cell 131, 1047-1058.

Cohen, D., Melamed, S., Millman, A., Shulman, G., Oppenheimer-Shaanan, Y., Kacen, A., et al. (2019). Cyclic GMP-AMP signalling protects bacteria against viral infection. Nature 574, 691-695. doi: 10.1038/s41586-019-1605-5

Commichau, F. M., Heidemann, J. L., Ficner, R., and Stülke, J. (2019). Making and Breaking of an Essential Poison: the Cyclases and Phosphodiesterases That Produce and Degrade the Essential Second Messenger Cyclic di-AMP in Bacteria. J. Bacteriol. 201, e00462-18. doi: 10.1128/JB.00462-18

Corrigan, R. M., and Gründling, A. (2013). Cyclic di-AMP: another second messenger enters the fray. Nat. Rev. Microbiol. 11, 513-524. doi: 10.1038/ nrmicro3069

Coste, H., Brevet, A., Plateau, P., and Blanquet, S. (1987). Non-adenylylated bis(5'-nucleosidyl) tetraphosphates occur in Saccharomyces cerevisiae and in Escherichia coli and accumulate upon temperature shift or exposure to cadmium. J. Biol. Chem. 262, 12096-12103. doi: 10.1016/s0021-9258(18) 45321-5

Crasnier, M. (1996). Cyclic AMP and catabolite repression. Res. Microbiol. 147, 479-482. doi: 10.1016/0923-2508(96)84002-2
Davies, B. W., Bogard, R. W., Young, T. S., and Mekalanos, J. J. (2012). Coordinated regulation of accessory genetic elements produces cyclic di-nucleotides for $\mathrm{V}$. cholerae virulence. Cell 149, 358-370. doi: 10.1016/j.cell.2012.01.053

Desch, M., Schinner, E., Kees, F., Hofmann, F., Seifert, R., and Schlossmann, J. (2010). Cyclic cytidine $3^{\prime}, 5^{\prime}$-monophosphate (cCMP) signals via cGMP kinase I. FEBS Lett. 584, 3979-3984. doi: 10.1016/j.febslet.2010.07.059

Diner, E. J., Burdette, D. L., Wilson, S. C., Monroe, K. M., Kellenberger, C. A., Hyodo, M., et al. (2013). The innate immune DNA sensor cGAS produces a noncanonical cyclic dinucleotide that activates human STING. Cell Rep. 3, 1355-1361. doi: 10.1016/j.celrep.2013.05.009

Dittmar, F., Abdelilah-Seyfried, S., Tschirner, S. K., Kaever, V., and Seifert, R. (2015). Temporal and organ-specific detection of cNMPs including cUMP in the zebrafish. Biochem. Biophys. Res. Commun. 468, 708-712. doi: 10.1016/j. bbrc.2015.11.020

Duggin, I. G., Aylett, C. H. S., Walsh, J. C., Michie, K. A., Wang, Q., Turnbull, L., et al. (2015). CetZ tubulin-like proteins control archaeal cell shape. Nature 519, 362-365. doi: 10.1038/nature13983

Escalante, R., Wessels, D., Soll, D. R., and Loomis, W. F. (1997). Chemotaxis to cAMP and slug migration in Dictyostelium both depend on migA, a BTB protein. Mol. Biol. Cell 8, 1763-1775. doi: 10.1091/mbc.8.9.1763

Fahmi, T., Port, G. C., and Cho, K. H. (2017). c-di-AMP: an Essential Molecule in the Signaling Pathways that Regulate the Viability and Virulence of GramPositive Bacteria. Genes 8:197. doi: 10.3390/genes 8080197

Ferguson, F., McLennan, A. G., Urbaniak, M. D., Jones, N. J., and Copeland, N. A. (2020). Re-evaluation of Diadenosine Tetraphosphate (Ap4A) From a Stress Metabolite to Bona Fide Secondary Messenger. Front. Mol. Biosci. 7:606807. doi: $10.3389 /$ fmolb.2020.606807

Flärdh, K., Axberg, T., Albertson, N. H., and Kjelleberg, S. (1994). Stringent control during carbon starvation of marine Vibrio sp. strain S14: molecular cloning, nucleotide sequence, and deletion of the relA gene. J. Bacteriol. 176, 5949-5957. doi: 10.1128/jb.176.19.5949-5957.1994

Flodgaard, H., and Klenow, H. (1982). Abundant amounts of diadenosine $5^{\prime}, 5^{\prime \prime}$ $\mathrm{P} 1, \mathrm{P} 4$-tetraphosphate are present and releasable, but metabolically inactive, in human platelets. Biochem. J. 208, 737-742. doi: 10.1042/bj2080737

Fontaine, B. M., Martin, K. S., Garcia-Rodriguez, J. M., Jung, C., Briggs, L., Southwell, J. E., et al. (2018). RNase I regulates Escherichia coli $2^{\prime}, 3^{\prime}$-cyclic nucleotide monophosphate levels and biofilm formation. Biochem. J. 475, 1491-1506. doi: 10.1042/BCJ20170906

Fraga, H., and Fontes, R. (2011). Enzymatic synthesis of mono and dinucleoside polyphosphates. Biochim. Biophys. Acta 1810, 1195-1204. doi: 10.1016/j. bbagen.2011.09.010

Gallant, J., Palmer, L., and Pao, C. C. (1977). Anomalous synthesis of ppGpp in growing cells. Cell 11, 181-185. doi: 10.1016/0092-8674(77)90329-4

Gancedo, J. M. (2013). Biological roles of cAMP: variations on a theme in the different kingdoms of life. Biol. Rev. 88, 645-668. doi: 10.1111/brv.12020

Gao, P., Ascano, M., Wu, Y., Barchet, W., Gaffney, B. L., Zillinger, T., et al. (2013). Cyclic $\left[\mathrm{G}\left(2^{\prime}, 5^{\prime}\right) \mathrm{pA}\left(3^{\prime}, 5^{\prime}\right) \mathrm{p}\right]$ is the metazoan second messenger produced by DNA-activated cyclic GMP-AMP synthase. Cell 153, 1094-1107. doi: 10.1016/ j.cell.2013.04.046

Garrison, P. N., and Barnes, L. D. (1984). Assay of adenosine 5'-P1-tetraphospho$\mathrm{P} 4-5{ }^{\prime \prime}$-adenosine and adenosine $5^{\prime}$-P1-tetraphospho-P4-5"'-guanosine in Physarum polycephalum and other eukaryotes. An isocratic high-pressure liquid-chromatography method. Biochem. J. 217, 805-811. doi: 10.1042/ bj2170805

Garrison, P. N., Mathis, S. A., and Barnes, L. D. (1989). Changes in diadenosine tetraphosphate levels in Physarum polycephalum with different oxygen concentrations. J. Bacteriol. 171, 1506-1512. doi: 10.1128/jb.171.3.1506-1512. 1989

Genschik, P., Billy, E., Swianiewicz, M., and Filipowicz, W. (1997). The human RNA 3 '-terminal phosphate cyclase is a member of a new family of proteins conserved in Eucarya, Bacteria and Archaea. EMBO J. 16, 2955-2967. doi: 10.1093/emboj/16.10.2955

Goldman, S. R., Sharp, J. S., Vvedenskaya, I. O., Livny, J., Dove, S. L., and Nickels, B. E. (2011). NanoRNAs prime transcription initiation in vivo. Mol. Cell 42, 817-825. doi: 10.1016/j.molcel.2011.06.005

Göttle, M., Dove, S., Kees, F., Schlossmann, J., Geduhn, J., König, B., et al. (2010). Cytidylyl and uridylyl cyclase activity of Bacillus anthracis edema factor and Bordetella pertussis CyaA. Biochemistry 49, 5494-5503. doi: 10.1021/bi100684g 
Hartwig, C., Bähre, H., Wolter, S., Beckert, U., Kaever, V., and Seifert, R. (2014). cAMP, cGMP, cCMP and cUMP concentrations across the tree of life: high cCMP and cUMP levels in astrocytes. Neurosci. Lett. 579, 183-187. doi: 10. 1016/j.neulet.2014.07.019

He, J., Yin, W., Galperin, M. Y., and Chou, S.-H. (2020). Cyclic di-AMP, a second messenger of primary importance: tertiary structures and binding mechanisms. Nucleic Acids Res. 48, 2807-2829. doi: 10.1093/nar/gkaa112

Hilgemann, D. W., Dai, G., Collins, A., Lariccia, V., Magi, S., Deisl, C., et al. (2018). Lipid signaling to membrane proteins: from second messengers to membrane domains and adapter-free endocytosis. J. Gen. Physiol. 150, 211-224. doi: 10.1085/jgp.201711875

Holleufer, A., Winther, K. G., Gad, H. H., Ai, X., Chen, Y., Li, L., et al. (2021). Two cGAS-like receptors induce antiviral immunity in Drosophila. Nature 597, 114-118. doi: 10.1038/s41586-021-03800-z

Hood, R. D., Higgins, S. A., Flamholz, A., Nichols, R. J., and Savage, D. F. (2016). The stringent response regulates adaptation to darkness in the cyanobacterium Synechococcus elongatus. Proc. Natl. Acad. Sci. U. S. A. 113, E4867-E4876. doi: $10.1073 /$ pnas. 1524915113

Ihara, Y., Ohta, H., and Masuda, S. (2015). A highly sensitive quantification method for the accumulation of alarmone ppGpp in Arabidopsis thaliana using UPLCESI-qMS/MS. J. Plant Res. 128, 511-518. doi: 10.1007/s10265-015-0711-1

Ito, D., Kawamura, H., Oikawa, A., Ihara, Y., Shibata, T., Nakamura, N., et al. (2020). ppGpp functions as an alarmone in metazoa. Commun. Biol. 3:671.

Jackson, E. K. (2011). The 2',3'-cAMP-adenosine pathway. Am. J. Physiol. Renal Physiol. 301, F1160-F1167.

Jackson, E. K. (2017). Discovery and Roles of $2^{\prime}, 3^{\prime}$-cAMP in Biological Systems. Handb. Exp. Pharmacol. 238, 229-252. doi: 10.1007/164_2015_40

Jia, X., Fontaine, B. M., Strobel, F., and Weinert, E. E. (2014). A facile and sensitive method for quantification of cyclic nucleotide monophosphates in mammalian organs: basal levels of eight cNMPs and identification of $2^{\prime}, 3^{\prime}$ cIMP. Biomolecules 4, 1070-1092. doi: 10.3390/biom4041070

Johnson, J.-L. F., and Leroux, M. R. (2010). cAMP and cGMP signaling: sensory systems with prokaryotic roots adopted by eukaryotic cilia. Trends Cell Biol. 20, 435-444. doi: 10.1016/j.tcb.2010.05.005

Kang, Y., Liu, R., Wu, J.-X., and Chen, L. (2019). Structural insights into the mechanism of human soluble guanylate cyclase. Nature 574, 206-210. doi: 10.1038/s41586-019-1584-6

Kazlauskiene, M., Kostiuk, G., Venclovas, È, Tamulaitis, G., and Siksnys, V. (2017). A cyclic oligonucleotide signaling pathway in type III CRISPR-Cas systems. Science 357, 605-609. doi: 10.1126/science.aao0100

Khannpnavar, B., Mehta, V., Qi, C., and Korkhov, V. (2020). Structure and function of adenylyl cyclases, key enzymes in cellular signaling. Curr. Opin. Struct. Biol. 63, 34-41. doi: 10.1016/j.sbi.2020.03.003

Kimura, Y., Tanaka, C., Sasaki, K., and Sasaki, M. (2017). High concentrations of intracellular Ap4A and/or Ap5A in developing Myxococcus xanthus cells inhibit sporulation. Microbiology 163, 86-93. doi: 10.1099/mic.0.000403

Koonin, E. V., and Makarova, K. S. (2018). Discovery of Oligonucleotide Signaling Mediated by CRISPR-Associated Polymerases Solves Two Puzzles but Leaves an Enigma. ACS Chem. Biol. 13, 309-312. doi: 10.1021/acschembio.7b00713

Kranzusch, P. J. (2019). cGAS and CD-NTase enzymes: structure, mechanism, and evolution. Curr. Opin. Struct. Biol. 59, 178-187. doi: 10.1016/j.sbi.2019.08.003

Kranzusch, P. J., Wilson, S. C., Lee, A. S. Y., Berger, J. M., Doudna, J. A., and Vance, R. E. (2015). Ancient Origin of cGAS-STING Reveals Mechanism of Universal 2',3' cGAMP Signaling. Mol. Cell 59, 891-903. doi: 10.1016/j.molcel.2015. 07.022

Kuipers, K., Gallay, C., Martínek, V., Rohde, M., Martínková, M., van der Beek, S. L., et al. (2016). Highly conserved nucleotide phosphatase essential for membrane lipid homeostasis in Streptococcus pneumoniae. Mol. Microbiol. 101, 12-26. doi: $10.1111 / \mathrm{mmi} .13312$

Kuwayama, H., Ecke, M., Gerisch, G., and Van Haastert, P. J. (1996). Protection against osmotic stress by cGMP-mediated myosin phosphorylation. Science 271, 207-209. doi: 10.1126/science.271.5246.207

Lazzarini, R. A., Cashel, M., and Gallant, J. (1971). On the regulation of guanosine tetraphosphate levels in stringent and relaxed strains of Escherichia coli. J. Biol. Chem. 246, 4381-4385. doi: 10.1016/s0021-9258(18)62023-x

Lee, P. C., Bochner, B. R., and Ames, B. N. (1983). AppppA, heat-shock stress, and cell oxidation. Proc. Natl. Acad. Sci. U. S. A. 80, 7496-7500. doi: 10.1073/pnas. 80.24 .7496
Lee, Y.-N., Nechushtan, H., Figov, N., and Razin, E. (2004). The function of lysyl-tRNA synthetase and Ap4A as signaling regulators of MITF activity in FcepsilonRI-activated mast cells. Immunity 20, 145-151. doi: 10.1016/s10747613(04)00020-2

Leichtling, B. H., Rickenberg, H. V., Seely, R. J., Fahrney, D. E., and Pace, N. R. (1986). The occurrence of cyclic AMP in archaebacteria. Biochem. Biophys. Res. Commun. 136, 1078-1082. doi: 10.1016/0006-291x(86)90443-2

Leung, S. W. S., Gao, Y., and Vanhoutte, P. M. (2015). “ 3 ', $5^{\prime}$-cIMP as Potential Second Messenger in the Vascular Wall," in Non-canonical Cyclic Nucleotides, ed. R. Seifert (Cham: Springer International Publishing), 209-228. doi: 10.1007/ 164_2015_39

Li, F., Cimdins, A., Rohde, M., Jänsch, L., Kaever, V., Nimtz, M., et al. (2019). DncV Synthesizes Cyclic GMP-AMP and Regulates Biofilm Formation and Motility in Escherichia coli ECOR31. mBio 10, e02492-18. doi: 10.1128/mBio.02 492-18

Liscovitch, M., and Cantley, L. C. (1994). Lipid second messengers. Cell 77, 329-334. doi: 10.1016/0092-8674(94)90148-1

Liu, C., Sun, D., Zhu, J., Liu, J., and Liu, W. (2020). The Regulation of Bacterial Biofilm Formation by cAMP-CRP: a Mini-Review. Front. Microbiol. 11:802. doi: $10.3389 /$ fmicb.2020.00802

Magnusson, L. U., Farewell, A., and Nyström, T. (2005). ppGpp: a global regulator in Escherichia coli. Trends Microbiol. 13, 236-242. doi: 10.1016/j.tim.2005. 03.008

Maiellaro, I., Lohse, M. J., Kittel, R. J., and Calebiro, D. (2016). cAMP Signals in Drosophila Motor Neurons Are Confined to Single Synaptic Boutons. Cell Rep. 17, 1238-1246. doi: 10.1016/j.celrep.2016.09.090

Maier, L.-K., Stachler, A.-E., Brendel, J., Stoll, B., Fischer, S., Haas, K. A., et al. (2019). The nuts and bolts of the Haloferax CRISPR-Cas system I-B. RNA Biol. 16, 469-480. doi: 10.1080/15476286.2018.1460994

Marden, J. N., Dong, Q., Roychowdhury, S., Berleman, J. E., and Bauer, C. E. (2011). Cyclic GMP controls Rhodospirillum centenum cyst development. Mol. Microbiol. 79, 600-615. doi: 10.1111/j.1365-2958.2010.07513.x

Marx, J. L. (1972). Cyclic AMP in Brain: role in Synaptic Transmission. Science 178, 1188-1190. doi: 10.1126/science.178.4066.1188

McDonough, K. A., and Rodriguez, A. (2011). The myriad roles of cyclic AMP in microbial pathogens: from signal to sword. Nat. Rev. Microbiol. 10, 27-38. doi: $10.1038 /$ nrmicro 2688

McLennan, A. G., and Prescott, M. (1984). Diadenosine 5',5'”-P1,P4 tetraphosphate in developing embryos of Artemia. Nucleic Acids Res. 12, 1609-1619. doi: 10.1093/nar/12.3.1609

Miras-Portugal, M. T., Pintor, J., and Gualix, J. (2003). Ca2+ signalling in brain synaptosomes activated by dinucleotides. J. Membr. Biol. 194, 1-10. doi: 10 . 1007/s00232-003-2024-x

Monds, R. D., Newell, P. D., Wagner, J. C., Schwartzman, J. A., Lu, W., Rabinowitz, J. D., et al. (2010). Di-adenosine tetraphosphate (Ap4A) metabolism impacts biofilm formation by Pseudomonas fluorescens via modulation of c-diGMP-dependent pathways. J. Bacteriol. 192, 3011-3023. doi: 10.1128/JB.01 571-09

Nan, Y., Zeng, X., Jin, Z., Li, N., Chen, Z., Chen, J., et al. (2020). PDE1 or PDE5 inhibition augments NO-dependent hypoxic constriction of porcine coronary artery via elevating inosine $3^{\prime}, 5^{\prime}$-cyclic monophosphate level. J. Cell. Mol. Med. 24, 14514-14524. doi: $10.1111 / \mathrm{jcmm} .16078$

Newton, A. C., Bootman, M. D., and Scott, J. D. (2016). Second Messengers. Cold Spring Harb. Perspect. Biol. 8:a005926.

Newton, R. P., Kingston, E. E., and Overton, A. (1998). Mass spectrometric identification of cyclic nucleotides released by the bacterium Corynebacterium murisepticum into the culture medium. Rapid Commun. Mass Spectrom. 12, 729-735. doi: 10.1002/(sici)1097-0231(19980615)12:11<729::aid-rcm217>3.0. co;2-b

Nickels, B. E., and Dove, S. L. (2011). NanoRNAs: a class of small RNAs that can prime transcription initiation in bacteria. J. Mol. Biol. 412, 772-781. doi: 10.1016/j.jmb.2011.06.015

Niewoehner, O., Garcia-Doval, C., Rostøl, J. T., Berk, C., Schwede, F., and Bigler, L. (2017). Type III CRISPR-Cas systems produce cyclic oligoadenylate second messengers. Nature 548, 543-548. doi: 10.1038/nature23467

Nisbett, L.-M., and Boon, E. M. (2016). Nitric Oxide Regulation of H-NOX Signaling Pathways in Bacteria. Biochemistry 55, 4873-4884. doi: 10.1021/acs. biochem.6b00754 
Nishimura, A., Moriya, S., Ukai, H., Nagai, K., Wachi, M., and Yamada, Y. (1997). Diadenosine $5^{\prime}, 5^{\prime \prime \prime}$-P1,P4-tetraphosphate (Ap4A) controls the timing of cell division in Escherichia coli. Genes Cells 2, 401-413. doi: 10.1046/j.1365-2443. 1997.1300328.x

Pabst, M., Grass, J., Fischl, R., Léonard, R., Jin, C., Hinterkörner, G., et al. (2010). Nucleotide and nucleotide sugar analysis by liquid chromatographyelectrospray ionization-mass spectrometry on surface-conditioned porous graphitic carbon. Anal. Chem. 82, 9782-9788. doi: 10.1021/ac101975k

Pálfi, Z., Surányi, G., and Borbély, G. (1991). Alterations in the accumulation of adenylylated nucleotides in heavy-metal-ion-stressed and heat-stressed Synechococcus sp. strain PCC 6301, a cyanobacterium, in light and dark. Biochem. J. 276, 487-491. doi: 10.1042/bj2760487

Paul, R., Weiser, S., Amiot, N. C., Chan, C., Schirmer, T., Giese, B., et al. (2004). Cell cycle-dependent dynamic localization of a bacterial response regulator with a novel di-guanylate cyclase output domain. Genes Dev. 18, 715-727. doi: $10.1101 /$ gad.289504

Plesner, P., and Ottesen, M. (1980). Determination of diadenosine tetraphosphate in biological material by high pressure liquid chromatography. Carlsberg Res. Commun. 45, 1-8. doi: 10.1016/0003-2697(83)90313-5

Rall, T. W., and Sutherland, E. W. (1958). Formation of a cyclic adenine ribonucleotide by tissue particles. J. Biol. Chem. 232, 1065-1076. doi: 10.1016/ s0021-9258(19)77422-5

Rao, F., See, R. Y., Zhang, D., Toh, D. C., Ji, Q., and Liang, Z.-X. (2010). YybT Is a Signaling Protein That Contains a Cyclic Dinucleotide Phosphodiesterase Domain and a GGDEF Domain with ATPase Activity. J. Biol. Chem. 285, 473-482. doi: 10.1074/jbc.M109.040238

Ren, J., Mi, Z., Stewart, N. A., and Jackson, E. K. (2009). Identification and quantification of $2^{\prime}, 3^{\prime}$-cAMP release by the kidney. J. Pharmacol. Exp. Ther. 328, 855-865. doi: 10.1124/jpet.108.146712

Römling, U. (2008). Great times for small molecules: c-di-AMP, a second messenger candidate in Bacteria and Archaea. Sci. Signal. 1:e39. doi: 10.1126/ scisignal.133pe39

Römling, U., Galperin, M. Y., and Gomelsky, M. (2013). Cyclic di-GMP: the first 25 years of a universal bacterial second messenger. Microbiol. Mol. Biol. Rev. 77, 1-52. doi: 10.1128/MMBR.00043-12

Römling, U., Gomelsky, M., and Galperin, M. Y. (2005). C-di-GMP: the dawning of a novel bacterial signalling system. Mol. Microbiol. 57, 629-639. doi: 10.1111/ j.1365-2958.2005.04697.x

Rosenberg, J., Dickmanns, A., Neumann, P., Gunka, K., Arens, J., Kaever, V., et al. (2015). Structural and biochemical analysis of the essential diadenylate cyclase CdaA from Listeria monocytogenes. J. Biol. Chem. 290, 6596-6606. doi: 10.1074/jbc.M114.630418

Rouillon, C., Athukoralage, J. S., Graham, S., Grüschow, S., and White, M. F. (2018). Control of cyclic oligoadenylate synthesis in a type III CRISPR system. Elife 7:e36734. doi: 10.7554/eLife.36734

Rybalkin, S. D., Yan, C., Bornfeldt, K. E., and Beavo, J. A. (2003). Cyclic GMP phosphodiesterases and regulation of smooth muscle function. Circ. Res. 93, 280-291. doi: 10.1161/01.res.0000087541.15600.2b

Ryjenkov, D. A., Tarutina, M., Moskvin, O. V., and Gomelsky, M. (2005). Cyclic diguanylate is a ubiquitous signaling molecule in bacteria: insights into biochemistry of the GGDEF protein domain. J. Bacteriol. 187, 1792-1798. doi: 10.1128/JB.187.5.1792-1798.2005

Schäfer, H., Beckert, B., Frese, C. K., Steinchen, W., Nuss, A. M., Beckstette, M., et al. (2020). The alarmones (p)ppGpp are part of the heat shock response of Bacillus subtilis. PLoS Genet. 16:e1008275. doi: 10.1371/journal.pgen.1008275

Scoarughi, G. L., Cimmino, C., and Donini, P. (1995). Lack of production of (p)ppGpp in Halobacterium volcanii under conditions that are effective in the eubacteria. J. Bacteriol. 177, 82-85. doi: 10.1128/jb.177.1.82-85.1995

Seifert, R. (2015). cCMP and cUMP: emerging second messengers. Trends Biochem. Sci. 40, 8-15. doi: 10.1016/j.tibs.2014.10.008

Seifert, R. (2017). "cCMP and cUMP Across the Tree of Life: From cCMP and cUMP Generators to cCMP- and cUMP-Regulated Cell Functions," in Non-canonical Cyclic Nucleotides, ed. R. Seifert (Cham: Springer International Publishing), 3-23. doi: 10.1007/164_2016_5005

Severin, G. B., Ramliden, M. S., Hawver, L. A., Wang, K., Pell, M. E., Kieninger, A.-K., et al. (2018). Direct activation of a phospholipase by cyclic GMP-AMP in El Tor Vibrio cholerae. Proc. Natl. Acad. Sci. U. S. A. 115, E6048-E6055. doi: $10.1073 /$ pnas. 1801233115
Shemarova, I. V. (2009). cAMP-dependent signal pathways in unicellular eukaryotes. Crit. Rev. Microbiol. 35, 23-42. doi: 10.1080/10408410802645646

Shigematsu, M., Kawamura, T., and Kirino, Y. (2018). Generation of $2^{\prime}, 3^{\prime}$-Cyclic Phosphate-Containing RNAs as a Hidden Layer of the Transcriptome. Front. Genet. 9:562. doi: 10.3389/fgene.2018.00562

Slavik, K. M., Morehouse, B. R., Ragucci, A. E., Zhou, W., Ai, X., Chen, Y., et al. (2021). cGAS-like receptors sense RNA and control $3^{\prime} 2^{\prime}$-cGAMP signaling in Drosophila. Nature 597, 109-113. doi: 10.1038/s41586-021-03743-5

Smith, K. D., Lipchock, S. V., and Strobel, S. A. (2012). Structural and biochemical characterization of linear dinucleotide analogues bound to the c-di-GMP-I aptamer. Biochemistry 51, 425-432. doi: 10.1021/bi2016662

Spangler, C., Böhm, A., Jenal, U., Seifert, R., and Kaever, V. (2010). A liquid chromatography-coupled tandem mass spectrometry method for quantitation of cyclic di-guanosine monophosphate. J. Microbiol. Methods 81, 226-231. doi: 10.1016/j.mimet.2010.03.020

Spira, B., Silberstein, N., and Yagil, E. (1995). Guanosine 3',5'-bispyrophosphate (ppGpp) synthesis in cells of Escherichia coli starved for Pi. J. Bacteriol. 177, 4053-4058. doi: 10.1128/jb.177.14.4053-4058.1995

Stelitano, V., Giardina, G., Paiardini, A., Castiglione, N., Cutruzzolà, F., and Rinaldo, S. (2013). C-di-GMP hydrolysis by Pseudomonas aeruginosa HD-GYP phosphodiesterases: analysis of the reaction mechanism and novel roles for pGpG. PLoS One 8:e74920. doi: 10.1371/journal.pone.0074920

Stryer, L. (1986). Cyclic GMP cascade of vision. Annu. Rev. Neurosci. 9, 87-119. doi: 10.1146/annurev.ne.09.030186.000511

Stülke, J., and Krüger, L. (2020). Cyclic di-AMP Signaling in Bacteria. Annu. Rev. Microbiol. 74, 159-179. doi: 10.1146/annurev-micro-020518-115943

Sutherland, E. W., and Wosilait, W. D. (1956). The relationship of epinephrine and glucagon to liver phosphorylase. I. Liver phosphorylase; preparation and properties. J. Biol. Chem. 218, 459-468. doi: 10.1016/s0021-9258(18)6 5909-5

Tal, N., Morehouse, B. R., Millman, A., Stokar-Avihail, A., Avraham, C., Fedorenko, T., et al. (2021). Cyclic CMP and cyclic UMP mediate bacterial immunity against phages. Cell. [Online ahead of print], . doi: 10.1016/j.cell.2021.09.031

Tarusawa, T., Ito, S., Goto, S., Ushida, C., Muto, A., and Himeno, H. (2016). (p)ppGpp-dependent and -independent pathways for salt tolerance in Escherichia coli. J. Biochem. 160, 19-26. doi: 10.1093/jb/mvw008

Thompson, J. E., Venegas, F. D., and Raines, R. T. (1994). Energetics of catalysis by ribonucleases: fate of the $2^{\prime}, 3^{\prime}$-cyclic phosphodiester intermediate. Biochemistry 33, 7408-7414. doi: 10.1021/bi00189a047

Tozawa, Y., and Nomura, Y. (2011). Signalling by the global regulatory molecule ppGpp in bacteria and chloroplasts of land plants. Plant Biol. 13, 699-709. doi: $10.1111 / j .1438-8677.2011 .00484 . x$

Uematsu, K., and Fukui, Y. (2008). Role and regulation of cAMP in seed germination of Phacelia tanacetifolia. Plant Physiol. Biochem. 46, 768-774. doi: 10.1016/j.plaphy.2007.10.015

Vahlensieck, U., Bokník, P., Gombosová, I., Huke, S., Knapp, J., Linck, B., et al. (1999). Inotropic effects of diadenosine tetraphosphate (AP4A) in human and animal cardiac preparations. J. Pharmacol. Exp. Ther. 288, 805-813.

Valentini, M., and Filloux, A. (2016). Biofilms and Cyclic di-GMP (c-di-GMP) Signaling: lessons from Pseudomonas aeruginosa and Other Bacteria. J. Biol. Chem. 291, 12547-12555. doi: 10.1074/jbc.R115.711507

Valentini, M., and Filloux, A. (2019). Multiple Roles of c-di-GMP Signaling in Bacterial Pathogenesis. Annu. Rev. Microbiol. 73, 387-406. doi: 10.1146/ annurev-micro-020518-115555

Van Damme, T., Blancquaert, D., Couturon, P., Van Der Straeten, D., Sandra, P., and Lynen, F. (2014). Wounding stress causes rapid increase in concentration of the naturally occurring $2^{\prime}, 3^{\prime}$-isomers of cyclic guanosine- and cyclic adenosine monophosphate (cGMP and cAMP) in plant tissues. Phytochemistry 103, 59-66. doi: 10.1016/j.phytochem.2014.03.013

Vinella, D., Albrecht, C., Cashel, M., and D'Ari, R. (2005). Iron limitation induces SpoT-dependent accumulation of ppGpp in Escherichia coli. Mol. Microbiol. 56, 958-970. doi: 10.1111/j.1365-2958.2005.04601.x

Vogt, M. S., Ngouoko Nguepbeu, R. R., Mohr, M. K. F., Albers, S.-V., Essen, L.O., and Banerjee, A. (2021). The archaeal triphosphate tunnel metalloenzyme SaTTM defines structural determinants for the diverse activities in the CYTH protein family. J. Biol. Chem. 297:100820. doi: 10.1016/j.jbc.2021.100820

Whiteley, A. T., Eaglesham, J. B., de Oliveira Mann, C. C., Morehouse, B. R., Lowey, B., Nieminen, E. A., et al. (2019). Bacterial cGAS-like enzymes synthesize 
diverse nucleotide signals. Nature 567, 194-199. doi: 10.1038/s41586-0190953-5

Witte, G., Hartung, S., Büttner, K., and Hopfner, K.-P. (2008). Structural biochemistry of a bacterial checkpoint protein reveals diadenylate cyclase activity regulated by DNA recombination intermediates. Mol. Cell 30, 167-178. doi: 10.1016/j.molcel.2008.02.020

Wolfe, A. J., and Visick, K. L. (2008). Get the message out: cyclic-Di-GMP regulates multiple levels of flagellum-based motility. J. Bacteriol. 190, 463-475. doi: 10.1128/JB.01418-07

Wolter, S., Golombek, M., and Seifert, R. (2011). Differential activation of cAMP- and cGMP-dependent protein kinases by cyclic purine and pyrimidine nucleotides. Biochem. Biophys. Res. Commun. 415, 563-566. doi: 10.1016/j.bbrc. 2011.10.093

Wu, J., Sun, L., Chen, X., Du, F., Shi, H., Chen, C., et al. (2013). Cyclic GMP-AMP is an endogenous second messenger in innate immune signaling by cytosolic DNA. Science 339, 826-830. doi: 10.1126/science. 1229963

Zhang, X., Shi, H., Wu, J., Zhang, X., Sun, L., Chen, C., et al. (2013). Cyclic GMPAMP containing mixed phosphodiester linkages is an endogenous high-affinity ligand for STING. Mol. Cell 51, 226-235. doi: 10.1016/j.molcel.2013.05.022

Zhou, L., and Zhu, D.-Y. (2009). Neuronal nitric oxide synthase: structure, subcellular localization, regulation, and clinical implications. Nitric oxide Biol. Chem. 20, 223-230. doi: 10.1016/j.niox.2009.03.001

Zink, I. A., Fouqueau, T., Tarrason Risa, G., Werner, F., Baum, B., Bläsi, U., et al. (2021). Comparative CRISPR type III-based knockdown of essential genes in hyperthermophilic Sulfolobales and the evasion of lethal gene silencing. RNA Biol. 18, 421-434. doi: 10.1080/15476286.2020.1813411

Zong, X., Krause, S., Chen, C.-C., Krüger, J., Gruner, C., Cao-Ehlker, X., et al. (2012). Regulation of Hyperpolarization-activated Cyclic Nucleotide-gated (HCN) Channel Activity by cCMP. J. Biol. Chem. 287, 26506-26512.

Conflict of Interest: The authors declare that the research was conducted in the absence of any commercial or financial relationships that could be construed as a potential conflict of interest.

Publisher's Note: All claims expressed in this article are solely those of the authors and do not necessarily represent those of their affiliated organizations, or those of the publisher, the editors and the reviewers. Any product that may be evaluated in this article, or claim that may be made by its manufacturer, is not guaranteed or endorsed by the publisher.

Copyright (C) 2021 Braun, Recalde, Bähre, Seifert and Albers. This is an openaccess article distributed under the terms of the Creative Commons Attribution License (CC BY). The use, distribution or reproduction in other forums is permitted, provided the original author(s) and the copyright owner(s) are credited and that the original publication in this journal is cited, in accordance with accepted academic practice. No use, distribution or reproduction is permitted which does not comply with these terms. 